\title{
A Subdivision Method to Unify the Existing Latitude and Longitude Grids
}

\author{
Chengqi Cheng ${ }^{1}$, Xiaochong Tong ${ }^{2, *}$, Bo Chen ${ }^{1}$ and Weixin Zhai ${ }^{1}$ \\ 1 College of Engineering, Peking University, Beijing 100871, China; ccq@pku.edu.com (C.C.); \\ pkuchenbo@pku.edu.cn (B.C.); pkuzhaiweixin@gmail.com (W.Z.) \\ 2 Zhengzhou Institute of Surveying and Mapping, Zhengzhou 450001, China \\ * Correspondence: txchr@163.com; Tel.: +86-371-8163-6608 \\ Academic Editor: Wolfgang Kainz \\ Received: 14 May 2016; Accepted: 1 September 2016; Published: 13 September 2016
}

\begin{abstract}
As research on large regions of earth progresses, many geographical subdivision grids have been established for various spatial applications by different industries and disciplines. However, there is no clear relationship between the different grids and no consistent spatial reference grid that allows for information exchange and comprehensive application. Sharing and exchange of data across departments and applications are still at a bottleneck. It would represent a significant step forward to build a new grid model that is inclusive of or compatible with most of the existing geodesic grids and that could support consolidation and exchange within existing data services. This study designs a new geographical coordinate global subdividing grid with one dimension integer coding on a $2^{\mathrm{n}}$ tree (GeoSOT) that has $2^{\mathrm{n}}$ coordinate subdivision characteristics (global longitude and latitude subdivision) and can form integer hierarchies at degree, minute, and second levels. This grid has the multi-dimensional quadtree hierarchical characteristics of a digital earth grid, but also provides good consistency with applied grids, such as those used in mapping, meteorology, oceanography and national geographical, and three-dimensional digital earth grids. No other existing grid codes possess these characteristics.
\end{abstract}

Keywords: global subdivision; latitude and longitude grids; consistency analysis; isomorphism

\section{Introduction}

A large amount of research on global subdivision grids exists worldwide, including styles ranging from the ancient Chinese nine-square system, the kilometer grid, and the latitude and longitude grid to the modern global division grid. The theory behind global subdivisions is built on the knowledge and technological achievements accumulated over thousands of years [1].

Subdivision grids can be categorized according to their geometry into subdivision grids based on the latitude and longitude grid [1-3], those based on coordinate grids [4,5], polygonal subdivision grids based on polyhedrons [6-9], irregular and mixed subdivision grids [10], etc. According to spatial information service industries, grids are categorized into basic geographical information grids, worldwide reference systems (WRSs) or grid reference systems (GRSs) for remote satellite systems, navigation and positioning grids, etc. For general applications in different industries, there are different subdivision grids applicable to the mapping, meteorology, oceanography, environmental, urban planning and administrative sectors [1,11-13].

In general, the application of global subdivision grids has become an extensively promoted worldwide trend. However, the lack of a clear relationship between different spatial information application grids remains a significant problem, although many studies have confirmed individual industry-oriented applications or conventional standardized subdivision grids for different types of spatial information. The inconformity among different types of reference grids will definitely lead to 
inefficiency, redundancy and immeasurable complexity. For example, in the remote sensing world, there are several grids that are commonly used across scientific disciplines, including oceanography, mapping, ecology, meteorology, etc.; despite that, these common projections are often used to share information. It is inevitable that the joint utilization of various sources of data like overlay and resampling would become intolerable. No unified subdivision grid for information exchange and comprehensive application has been developed. A few efforts have been made recently on the hierarchical grid conversion along with the indexing methods [9,14]; however, the subdivision methods do not adapt to the existing geographical data in all types of applications, and the indexing efficiency needs further enhancement. Therefore, a globally consistent spatial information subdivision grid model that is compatible with most of the existing subdivision grid systems is needed. This system could quickly connect inter-departmental spatial information from multiple applications and unify their management to achieve rapid connection, exchange, and sharing of spatial information on a global scale.

\section{Latitude and Longitude Global Subdivision Grids}

Although subdivision grids have different forms across the world, the majority are based on latitude and longitude applications. It is therefore essential to construct a new grid model that is compatible with existing latitude and longitude subdivision grids, and can support unification and exchange for the majority of data services and applications in different industries. Therefore, this section reviews current latitude and longitude global grids to classify and summarize new research in recent years.

\subsection{Classification of Latitude and Longitude Global Subdivision Grids}

\subsubsection{Equal Latitude and Longitude Global Grid System}

An equal latitude and longitude global grid refers to a grid that segments Earth into multiple grid cells using equal latitude and longitude intervals. This system divides Earth's surface into cells using equal increments. Equal latitude and longitude grid systems have been widely used since before the age of computers, and form the basis of many existing spatial datasets, process algorithms, and software. The applications of equal latitude and longitude grid systems are essential for space-related data. Many international institutions have investigated equal latitude and longitude grids. National Aeronautics and Space Administration (NASA) released the open source software World Wind, a typical system that uses an equal latitude and longitude global subdivision [15], and sorts logically related images or terrains into datasets. The resolution of Level 0 can be any reasonable value, and other levels are recursively subdivided by equal latitude and longitude intervals. The hierarchical internal framework has been adopted in the original design in Virtual GIS to display terrain databases extending over large areas, at different resolutions [16]. Similarly, this hierarchical data structure provided high fidelity in real-time, three-dimensional visual simulation [17]. This solution also exists in SRI's digital earth project [18,19]. Many global datasets also adopt the equal latitude and longitude subdivision for data organization. For example, the GTOPO 30 dataset and ETOPO 5 dataset provided by the U.S. Geological Survey (USGS) and the JGP95E5' dataset provided by the Goddard Space Flight Center of NASA.

The interchange between latitude and longitude systems and other coordinate systems is relatively simple, and the related algorithms are well developed. However, there are obvious flaws in the equal latitude and longitude system.

(a) The complexity of statistical analysis due to the difference in grid cell areas.

(b) The system includes grid cell area deformation, shape deformation, and interior point positional errors incremented from equator to the poles.

(c) The cell shape at the top and bottom of the grid system is triangular rather than rectangular. 


\subsubsection{Variable Latitude and Longitude Global Grid Systems}

Recently, industries have proposed latitude and longitude grid subdivisions using variable intervals to keep grid cell areas in the same level approximately equal. A typical example is Ellipsoid Quad Tree (EQT) subdivision [20], which divides the globe by fixed latitude differences and variable longitude differences, or by fixed longitude differences and variable latitude differences. Google Earth also adopts a variable latitude and longitude global grid. The longitude differences are fixed while latitudes are divided by equal intervals based on the Universal Transverse Mercator (UTM) projection (the two poles receive separate treatments) [21]. Some global datasets also use variable latitude and longitude grids. For example, Digital Terrain Elevation Data (DTED) provided by the National Geospatial Intelligence Agency (NGA)'s predecessor, the National Imagery and Mapping Agency (NIMA), adopted the method of fixing latitude intervals (at three arc seconds) and incrementing longitudes from the equator to the poles [22]. Based on this, Bjørke adopted a smaller global grid scheme than DTED and further improved the equality of the grid cells' areas [23]. Additionally, the governments of Australia and New Zealand in the Landcare Research plan designed the SCENZ-Grid [24-26], which is used in spatial analyses and data gathering. SCENZ-Grid divided the globe into six regions: four between the 45th parallel north and the 45th parallel south, and two in high-latitude regions. Similar methods were also employed by Zhou et al. in their Quaternary Quadrangle Mesh [27].

Some recognized international organizations and global international projects have also designed specific variable latitude and longitude global grids. For example, the ISCCP Grid [28], designed by the International Satellite Cloud Climatology Project (ISCCP) adopts the method of dividing a cylindrical projection of Earth into horizontal zones. Earth is divided into 72 projection zones with a latitude width of $2.5^{\circ}$ before vertically dividing each projection zone into a variable number of parts such that every unit has the same area. Therefore, there are 144 segments on the equator but only three at the pole, as shown in Figure 1a. Additionally, the Parallel Ocean Program (POP) grid [29] and the Orca grid [30] are often used in global ocean and glacier simulations. They use uneven rectangular cells to cover the entire ocean while treating the poles separately, as shown in Figure 1b,c.

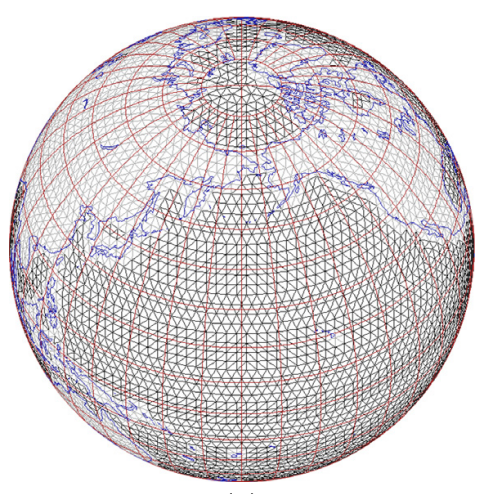

(a)

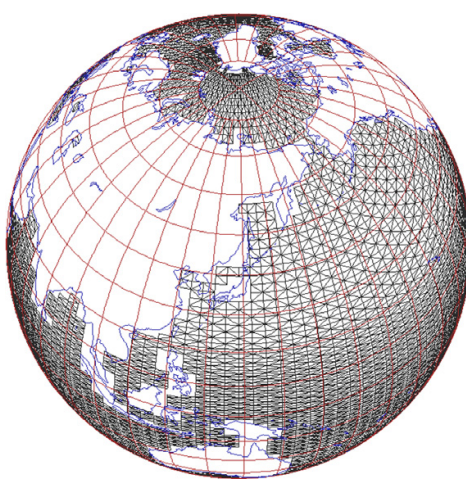

(b)

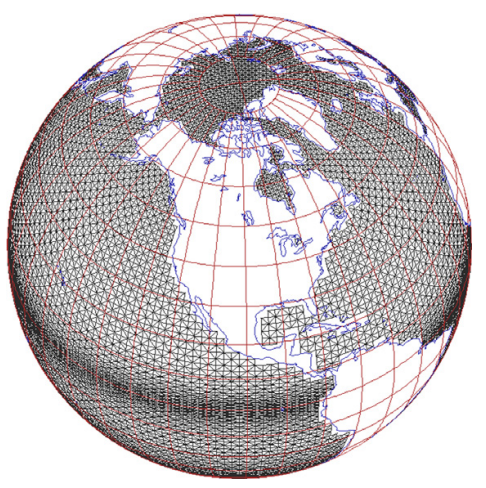

(c)

Figure 1. Some examples of variable latitude and longitude global subdivision grids. (a) ISCCP GRID; (b) POP GRID; (c) ORCA GRID.

\subsection{Industrial Applications of Latitude and Longitude Global Subdivision Grids}

Currently, there are many differing industrial applications of latitude and longitude global subdivision grids. Below are some representative domestic and international applications.

\subsubsection{United States National Grid (USNG) and Its Application}

The United States National Grid (USNG) is a planar position reference grid system proposed by the Federal Geographic Data Committee (FGDC) [31]. The main purpose of the USNG proposed by the 
FGDC was to create a set of spatial-positioning, fundamental, and national spatial information grids for the location-based service (LBS) that could be used collaboratively and operate interactively, and could also provide application support for the National Spatial Data Infrastructure (NSDI). If WGS84 and NAD83 are taken as spatial benchmarks, then the USNG within America is generally consistent with the Military Grid Reference System (MGRS).

\subsubsection{World Geographic Reference System (Georef) and Its Application}

The World Geographic Reference System, Georef, was proposed by the National GeospatialIntelligence Agency (NGA) of the United States [32]. It is an Earth surface location-description system based on latitude and longitude coordinates and is mainly used in aircraft navigation, especially in location reporting between combat units in the Air Force. It divides the Earth into five sections, constructs five levels of grids, and uses a code form of "four letters + four digits numbers + extended code".

\subsubsection{Global Area Reference System (GARS) and Its Applications}

The Global Area Reference System (GARS) was originally proposed by the NGA [33]. The aim was to develop a standardized geographical location code system suitable for spatial coordinate expression to meet the United States Department of Defense's need for cooperation between combat systems and commanding agencies. GARS did not aim to replace existing grid systems like Georef and MGRS, but to complement these systems and provide a simple, unified spatial location identification and measurement system for both air and ground applications.

\subsubsection{Application of Location Identification}

In the United States National Search and Rescue Committee's georeferencing regulations, the priorities for subdivision grids are to identify locations in service applications, including finding disaster relief response on land, achieving synergy between aviation and land operations, and coordinating land search and rescue responses [34]. Subdivision grids are also used to supplement latitude and longitude coordinates in other operations.

\subsubsection{Navigation and Positioning Applications}

The use of global subdivision grids and codes in satellite navigation is already widespread in the United States [31]. After embedding grid code software into GPS receivers, GPS navigation devices will output USNG (MGRS) grid codes at well as latitude and longitude coordinates. Users can directly use location codes to identify their locations and apply for navigation services.

\section{Unifying Latitude and Longitude Global Regular Hierarchical Grids}

As mentioned above, there are various latitude and longitude global grids in use in the commercial, scientific and engineering fields. It would be beneficial to combine these grids in a unified framework.

\subsection{The Aim of Unifying the Current Latitude and Longitude Grids}

We analyzed the unification for the cross industry and the cross business grids. The inconsistencies in both fields have resulted in a heavy load for the comprehensive applications. Accordingly, a well-defined unifying grid will undoubtedly promote efficiency among different sectors.

\subsubsection{Application Problems for Cross-Industry Grids}

Let $Y$ be a spatial information application field, e.g., mapping, meteorology, oceanography, environment and digital earth; and Data be the dataset of spatial information in field $\mathrm{Y}$.

Each field has its own data grid (e.g., Grid Mapping, $_{\text {, }}$ rid $_{\text {Meteorology, }}$ Grid $_{\text {Oceanography, }}$ Grid $_{\text {Environment }}$ Grid $\left._{\text {Digital Earth }}\right)$ based on latitude and longitude grids and designed to satisfy each industry's application needs. 
However, with the increased requirement for cross-industry applications, inconsistencies in different industry grid standards were found, despite some overlap in grid subdivisions. This currently causes significant difficulties or conversion costs for shared applications. The main purpose of this study is to explore common constituents of the different kinds of grids.

\subsubsection{Application Problems for Cross Business Process Grids}

Let $Y$ be a spatial information application field, and Data $y_{y}$ be a dataset of spatial information in field $Y$.

Management of Data $\mathrm{y}_{\mathrm{y}}$ includes storage, retrieval and visualization, and could also include processing and serving of Data $\mathrm{y}$. Each operational process has its own grid, Grid ${ }_{\mathrm{y}}{ }^{\text {Store }}, \mathrm{Grid}_{\mathrm{y}}{ }^{\text {Retrieval }}$, $\mathrm{Grid}_{\mathrm{y}}{ }^{\text {Visualize }}, \mathrm{Grid}_{\mathrm{y}}{ }^{\text {Process }}$ and $\mathrm{Grid}_{\mathrm{y}}$ Serve, designed to satisfy each process's application needs.

However, with the increasingly large amount of spatial information from multiple sources and real-time demand for cross-industry application processes, we found inconsistencies in the grid standards for different processes that made smooth migration between these grids difficult. Thus, it is an aim of this research to explore the constituents of the uniformity of different kinds of grids and the aggregation pattern. This study aims to develop a spatially consistent subdivision grid model of Earth's surface and to construct a spatial subdivision grid that increases the efficiency of data management integration between industries and businesses, through methods including indexing, aggregation, and substitution (Figure 2).

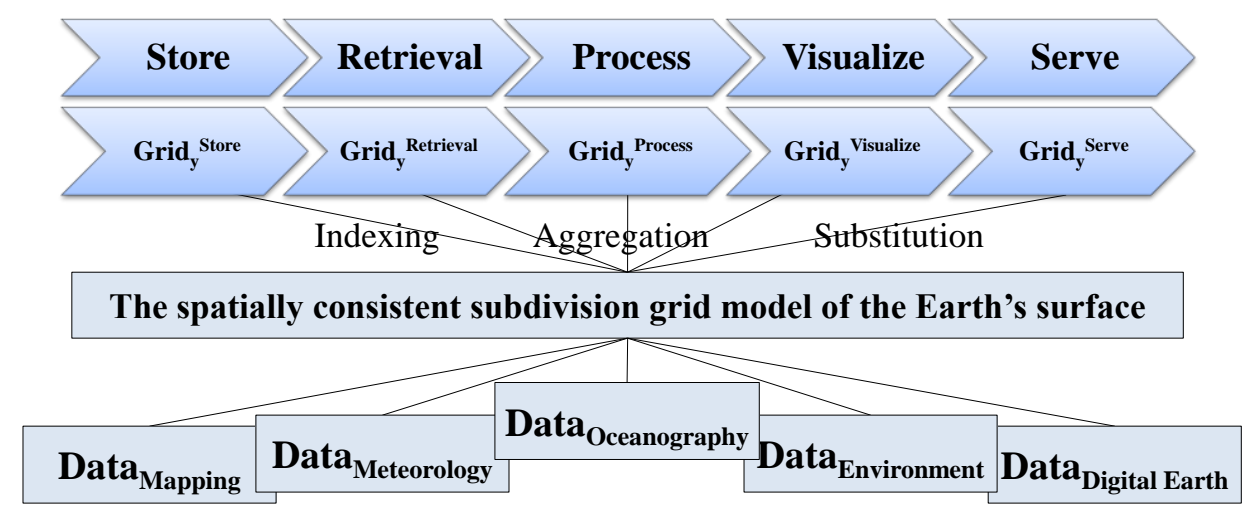

Figure 2. The concept of the spatially consistent subdivision grid model of Earth's surface.

\subsection{Constraint Analysis of the Consistency of Latitude and Longitude Grid Model Designs}

\subsubsection{Definition and Characteristics of Latitude and Longitude Grid Models}

Latitude and longitude subdivision grids are based on equal interval latitude and longitude grid subdivisions. The variable latitude and longitude grid subdivision is often obtained by varying the intervals along the latitudes and longitudes. The concept of the equal latitude and longitude grid subdivision is outlined below.

Definition 1: Let $\mathbb{G}$ be the set of all kinds of grids formed with latitudes and longitudes such that

$$
\mathbb{G}=\mathrm{f}(\mathrm{t}, \mathrm{b}, \mathrm{l}, \mathrm{r})
$$

The four variables $t, 1, b$ and $r$ in Equation (1) represent the lengths of the four sides of a grid cell, rotating anti-clockwise from north; $t, b, 1$ and $r$ are measured in degrees. Since the latitude and longitude grid is orthogonal, $\mathrm{t}$ and $\mathrm{b}$; and $\mathrm{l}$ and $\mathrm{r}$ are equivalent. 
The latitude and longitude grid investigated in this study is a hierarchical grid. Let the set of hierarchical grids be $C$ such that $C \subset \mathbb{G}$. Let $C_{k, i, j}$ be the cell in the $k^{\text {th }}$ level, the $\mathrm{i}^{\text {th }}$ row and the $\mathrm{j}^{\text {th }}$ column, and $\mathrm{C}_{\mathrm{k}, \mathrm{i}, \mathrm{j}} \in \mathrm{C}$ such that

$$
C_{k, i, j}=f\left(t_{k, i, j}, b_{k, i, j,}, l_{k, i, j}, r_{k, i, j}\right)
$$

We can divide hierarchical grids into two types:

The first type is equally divided grids, where the $\mathrm{k}^{\text {th }}$-level grid is divided into several equal sub-units as is the $(k+1)^{\text {th }}$ level;

The second type is the grids with equal intervals, where the $\mathrm{k}^{\text {th }}$-level grid consists of equidistant cells from the $(\mathrm{k}+1)^{\text {th }}$ level.

These two grids are generated differently: equally divided grids are divided from top to bottom, and the $\mathrm{k}+1^{\text {th }}$ level is generated by the $\mathrm{k}^{\text {th }}$ level; grids with equal intervals use combinations from bottom to top, and the $\mathrm{k}^{\text {th }}$ level is formed by the $\mathrm{k}+1^{\text {th }}$ level. It should be noted that there are some special cases of grids with equal intervals, in which the $\mathrm{k}^{\text {th }}$ level grid will be formed by several $\mathrm{k}+1^{\text {th }}$ complete grids and an incomplete row or column in either the $\mathrm{i}^{\text {th }}$ direction or the $\mathrm{j}^{\text {th }}$ direction. For example, a $5^{\circ} \times 1^{\circ}$ grid can be formed from two $2^{\circ} \times 1^{\circ}$ grids and one $1^{\circ} \times 1^{\circ}$ grid .

To determine the relationship between two adjacent levels, the number of sub-cells dividing a cell in the latitude or longitude direction for the $\mathrm{k}^{\text {th }}$-level grid is defined as the frequency; the product of the frequency for the two directions is defined as the aperture from the $\mathrm{k}^{\text {th }}$ to the $\mathrm{k}+1^{\text {th }}$ level.

Let the $\mathrm{k}^{\text {th }}$ level of a latitude and longitude grid be $C_{k, i, j}$ and the $k+1^{\text {th }}$ level be $C_{k+1, i^{\prime}, j^{\prime}}$. Let the frequency of the latitude direction (direction $\mathrm{i}$ ) be $\mathrm{m}$ and the aperture of the longitude direction (direction j) be n, such that

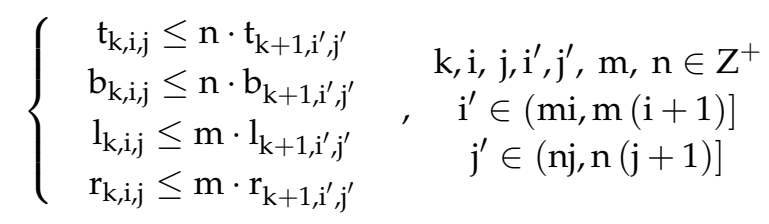

For the grid defined by Equation (3), the aperture $A_{k}$ from the $k^{\text {th }}$ level to the $k+1^{\text {th }}$ level is

$$
A_{k}=m \cdot n
$$

To improve the hierarchical grid's regularity, the system in this study must satisfy $\mathrm{A}_{0}=\mathrm{A}_{1}=$ $\cdots A_{k}=\cdots$. This type of latitude and longitude hierarchical grid is a uniform aperture latitude and longitude hierarchical grid.

(Case 1) When the " $\leq$ " in Equation (3) are replaced by "=", and

$$
\begin{gathered}
\mathrm{t}_{\mathrm{k}+1, \mathrm{mi}+1, \mathrm{nj}+1}=\mathrm{t}_{\mathrm{k}+1, \mathrm{mi}+1, \mathrm{nj}+2}=\cdots \mathrm{t}_{\mathrm{k}+1, \mathrm{mi}+1, \mathrm{nj}+\mathrm{n}}=\cdots=\mathrm{t}_{\mathrm{k}+1, \mathrm{mi}+\mathrm{m}, \mathrm{nj}+\mathrm{n}}=\frac{\mathrm{t}_{\mathrm{k}, \mathrm{i}, \mathrm{j}}}{\mathrm{n}}=\overline{\mathrm{t}_{\mathrm{k}+1}} \\
\mathrm{~b}_{\mathrm{k}+1, \mathrm{mi}+1, \mathrm{nj}+1}=\mathrm{b}_{\mathrm{k}+1, \mathrm{mi}+1, \mathrm{nj}+2}=\cdots \mathrm{b}_{\mathrm{k}+1, \mathrm{mi}+1, \mathrm{nj}+\mathrm{n}}=\cdots=\mathrm{b}_{\mathrm{k}+1, \mathrm{mi}+\mathrm{m}, \mathrm{nj}+\mathrm{n}}=\frac{\mathrm{b}_{\mathrm{k}, \mathrm{i}, \mathrm{j}}}{\mathrm{n}}=\overline{\mathrm{b}_{\mathrm{k}+1}} \\
\mathrm{l}_{\mathrm{k}+1, \mathrm{mi}+1, \mathrm{nj}+1}=\mathrm{l}_{\mathrm{k}+1, \mathrm{mi}+2, \mathrm{nj}+1}=\cdots \mathrm{l}_{\mathrm{k}+1, \mathrm{mi}+\mathrm{m}, \mathrm{nj}+1}=\cdots=\mathrm{l}_{\mathrm{k}+1, \mathrm{mi}+\mathrm{m}, \mathrm{nj}+\mathrm{n}}=\frac{\mathrm{l}_{\mathrm{k}, \mathrm{i}, \mathrm{j}}}{\mathrm{m}}=\overline{\mathrm{l}_{\mathrm{k}+1}} \\
\mathrm{r}_{\mathrm{k}+1, \mathrm{mi}+1, \mathrm{nj}+1}=\mathrm{r}_{\mathrm{k}+1, \mathrm{mi}+2, \mathrm{nj}+1}=\cdots \mathrm{r}_{\mathrm{k}+1, \mathrm{mi}+\mathrm{m}, \mathrm{nj}+1}=\cdots=\mathrm{r}_{\mathrm{k}+1, \mathrm{mi}+\mathrm{m}, \mathrm{nj}+\mathrm{n}}=\frac{\mathrm{r}_{\mathrm{k}, \mathrm{i}, \mathrm{j}}}{\mathrm{m}}=\overline{\mathrm{r}_{\mathrm{k}+1}}
\end{gathered}
$$

then $C$ is an equally divided grid. 
(Case 2) When Equation (3) is satisfied and

$$
\begin{gathered}
\mathrm{t}_{\mathrm{k}+1, \mathrm{mi}+1, \mathrm{nj}+1}=\cdots=\mathrm{t}_{\mathrm{k}+1, \mathrm{mi}+1, \mathrm{nj}+\mathrm{n}-1}=\cdots=\mathrm{t}_{\mathrm{k}+1, \mathrm{mi}+\mathrm{m}-1, \mathrm{nj}+\mathrm{n}-1}=\Delta \mathrm{t}_{\mathrm{k}+1} \\
\leq \mathrm{t}_{\mathrm{k}+1, \mathrm{mi}+1, \mathrm{nj}+\mathrm{n}}=\cdots=\mathrm{t}_{\mathrm{k}+1, \mathrm{mi}+\mathrm{m}, \mathrm{nj}+\mathrm{n}} \\
\mathrm{b}_{\mathrm{k}+1, \mathrm{mi}+1, \mathrm{nj}+1}=\cdots=\mathrm{b}_{\mathrm{k}+1, \mathrm{mi}+1, \mathrm{nj}+\mathrm{n}-1}=\cdots=\mathrm{b}_{\mathrm{k}+1, \mathrm{mi}+\mathrm{m}-1, \mathrm{nj}+\mathrm{n}-1}=\Delta \mathrm{b}_{\mathrm{k}+1} \\
\leq \mathrm{b}_{\mathrm{k}+1, \mathrm{mi}+1, \mathrm{nj}+\mathrm{n}}=\cdots=\mathrm{b}_{\mathrm{k}+1, \mathrm{mi}+\mathrm{m}, \mathrm{nj}+\mathrm{n}} \\
\mathrm{l}_{\mathrm{k}+1, \mathrm{mi}+1, \mathrm{nj}+1}=\cdots=\mathrm{l}_{\mathrm{k}+1, \mathrm{mi}+\mathrm{m}-1, \mathrm{nj}+1}=\cdots=\mathrm{l}_{\mathrm{k}+1, \mathrm{mi}+\mathrm{m}-1, \mathrm{nj}+\mathrm{n}-1}=\Delta \mathrm{l}_{\mathrm{k}+1} \\
\leq \mathrm{l}_{\mathrm{k}+1, \mathrm{mi}+\mathrm{m}, \mathrm{nj}+1}=\cdots=\mathrm{l}_{\mathrm{k}+1, \mathrm{mi}+\mathrm{m}, \mathrm{nj}+\mathrm{n}} \\
\mathrm{r}_{\mathrm{k}+1, \mathrm{mi}+1, \mathrm{nj}+1}=\cdots=\mathrm{r}_{\mathrm{k}+1, \mathrm{mi}+\mathrm{m}-1, \mathrm{nj}+1}=\cdots=\mathrm{r}_{\mathrm{k}+1, \mathrm{mi}+\mathrm{m}-1, \mathrm{nj}+\mathrm{n}-1}=\Delta \mathrm{r}_{\mathrm{k}+1} \\
\leq \mathrm{r}_{\mathrm{k}+1, \mathrm{mi}+\mathrm{m}, \mathrm{nj}+1}=\cdots=\mathrm{r}_{\mathrm{k}+1, \mathrm{mi}+\mathrm{m}, \mathrm{nj}+\mathrm{n}}
\end{gathered}
$$

then $C$ is a grid with equal intervals.

Equation (3) initially takes the form

$$
\mathrm{t}_{0,1,1}=\mathrm{L}_{\mathrm{t}}, \mathrm{b}_{0,1,1}=\mathrm{L}_{\mathrm{b}}, \mathrm{l}_{0,1,1}=\mathrm{L}_{1}, \mathrm{r}_{0,1,1}=\mathrm{L}_{\mathrm{r}}
$$

where $L_{t}, L_{b}, B_{1}$ and $B_{r}$ are the longitude and latitude lengths of the $0^{\text {th }}$ level grid (in degrees).

When $\mathrm{m}$ and $\mathrm{n}$ for different levels are equal, equally divided grids and grids with equal intervals can be expressed with the two different definitions. When $\overline{t_{k+1}}=\Delta t_{k+1}, \overline{b_{k+1}}=\Delta b_{k+1}$, $\overline{\mathrm{l}_{\mathrm{k}+1}}=\Delta \mathrm{l}_{\mathrm{k}+1}, \overline{\mathrm{r}_{\mathrm{k}+1}}=\Delta \mathrm{r}_{\mathrm{k}+1}$ and the " $\leq$ " in Equation (3) are replaced by " $=$ ", C equally divided grids as well as grids with equal intervals.

Definition 2: For global latitude and longitude grids $\mathbf{C} 1$ and $\mathbf{C} 2, \mathrm{C}_{\mathrm{k}_{1}}$ and $\mathrm{C} 2_{\mathrm{k}_{2}}$ are the grid cells of $\mathbf{C} \mathbf{1}$ in the $\mathrm{k}_{1}{ }^{\text {th }}$ level and $\mathrm{C} 2$ in the $\mathrm{k}_{2}{ }^{\text {th }}$ level, respectively. If the area covered by $\mathrm{X} \times \mathrm{Y}\left(\mathrm{X}, \mathrm{Y} \in N^{+}\right)$adjacent to $\mathrm{C}_{\mathrm{k}_{1}}$ is the same as $\mathrm{C} 2_{\mathrm{k}_{2}}$, then $\mathbf{C} \mathbf{1}$ can be aggregated to $\mathbf{C} 2$, as in Equation (8). When $\mathbf{C} \mathbf{1}=\mathbf{C} 2, \mathbf{C} \mathbf{1}$ can be aggregated to $\mathbf{C} \mathbf{1}$.

$$
\begin{aligned}
& t_{k_{1}, i, j}=X \cdot t_{k_{2}, i^{\prime}, j^{\prime}}, b_{k_{1}, i, j}=X \cdot b_{k_{2}, i^{\prime}, j^{\prime}} \\
& l_{k_{1}, i, j}=Y \cdot l_{k_{2}, i^{\prime}, j^{\prime},} r_{k_{1}, i, j}=Y \cdot r_{k_{2}, i^{\prime}, j^{\prime}}
\end{aligned}
$$

\subsubsection{Constraints for Constructing Consistent Latitude and Longitude Grid Models}

The aim of this study is to find a consistent latitude and longitude grid model, which has better aggregation with existing latitude and longitude grid systems and satisfies the characteristics of having uniform aperture. Also, to conform with the isotropic characteristics of geospace, cells of each grid level must be square, i.e., $\mathrm{t}=\mathrm{b}=1=\mathrm{r}$. The following three steps should therefore constrain a consistent latitude and longitude grid.

1 Find the basic grid (square grid) $R_{\text {basic }}$ for a consistent latitude and longitude grid that is suitable as a basic component unit:

$$
\left(\begin{array}{c}
\mathrm{R}_{\text {lat }} \\
\mathrm{R}_{\text {long }}
\end{array}\right)=\left(\mathrm{n}_{\text {lat }}, \mathrm{n}_{\text {long }}\right)\left(\begin{array}{c}
\mathrm{R}_{\text {basic }} \\
\mathrm{R}_{\text {basic }}
\end{array}\right)
$$

To ensure the effectiveness of the consistent grid, $R_{\text {basic }}$ should be the largest grid that can be aggregated into other types of latitude and longitude grids. For example, the national basic map scale 1:1,000,000 (without considering combined maps) constitutes an equal latitude and longitude grid with an interval of $4^{\circ}$ in latitude and $6^{\circ}$ in longitude. Its basic unit is $2^{\circ}$ rather than $1^{\circ}$ :

$$
\left(\begin{array}{l}
6^{\circ} \\
4^{\circ}
\end{array}\right)=(3,2)\left(\begin{array}{l}
2^{\circ} \\
2^{\circ}
\end{array}\right)=(6,4)\left(\begin{array}{l}
1^{\circ} \\
1^{\circ}
\end{array}\right)
$$

2 The forms of consistent latitude and longitude grids 
By analyzing the common latitude and longitude grid systems, (e.g., the basic scale topographic map framing systems of various countries; the Chinese national geographic grid system, the U.S. military grid reference system, and the meteorological, marine, and other industries' grid systems) most latitude and longitude grid systems were found to be regularly divided by the degrees, minutes, and seconds of latitude and longitude. In other words, the size of the sub-cells is rounded up to the nearest absolute degree, minute, or second. Where sub-cells are smaller than 1 ", the cells are divided with seconds as the relevant unit. Therefore, when designing a consistent latitude and longitude grid model, the new grid system should contain latitude and longitude grids with three specifications: $1^{\circ}$, $1^{\prime}$ and $1^{\prime \prime}$. Therefore, different levels of the new system should be integer multiples or integer fractions of $1^{\circ}, 1^{\prime}$ and $1^{\prime \prime}$, and it is reasonable to define consistent latitude and longitude grid models using grids with equal intervals.

3 Parameter selection of consistent latitude and longitude grids.

To make a consistent latitude and longitude grid model in line with data organization methods (i.e., three-dimensional visualized digital earth platforms such as Google Earth, World Wind and Map World) and to ensure the upper and lower levels form a quadtree pyramid structure, the new model should be subdivided level-by-level using an aperture size of four. Moreover, the subdividing frequency in both the latitude and longitude directions should be two. Therefore, the basic grid must be a multiple of $2^{n}(n \in Z)$ and $1^{\circ}, 1^{\prime}$ and $1^{\prime \prime}$.

The following is an example analysis of the Chinese national basic scale map grid [35]. The Chinese national basic scale for map sheets includes eight different basic grids, 1:1,000,000 $\left(6^{\circ} \times 4^{\circ}\right), 1: 500,000$ $\left(3^{\circ} \times 2^{\circ}\right), 1: 250,000\left(1^{\circ} 30^{\prime} \times 1^{\circ}\right), 1: 100,000\left(30^{\prime} \times 20^{\prime}\right), 1: 50,000\left(15^{\prime} \times 10^{\prime}\right), 1: 25,000\left(7^{\prime} 30^{\prime \prime} \times 5^{\prime}\right)$, $1: 10,000\left(3^{\prime} 45^{\prime \prime} \times 2^{\prime} 30^{\prime \prime}\right)$ and 1:5,000 $\left(1^{\prime} 52.5^{\prime \prime} \times 1^{\prime} 15^{\prime \prime}\right)$, formed using the equal latitude and longitude subdivision method. In the cases of combined maps, the new grid would be the combination of any of the aforementioned basic grids. According to definition 2, any new grid can be aggregated by eight grids: $2^{\circ}, 1^{\circ}, 30^{\prime}, 10^{\prime}, 5^{\prime}, 30^{\prime \prime}, 5^{\prime \prime}$ and $0.5^{\prime \prime}$, as shown in Table 1 .

Table 1. Chinese national basic scale map grid analysis.

\begin{tabular}{ccccccc}
\hline Scale & Size of Grid & $\begin{array}{c}\text { Frequency of } \\
\text { Longitude }(\boldsymbol{m})\end{array}$ & $\begin{array}{c}\text { Frequency of } \\
\text { Latitude }(\boldsymbol{m})\end{array}$ & Aperture & $\boldsymbol{R}_{\text {Basic }}$ & $\left(\boldsymbol{n}_{\text {lat }}, \boldsymbol{n}_{\text {long }}\right)$ \\
\hline Global & $360^{\circ} \times 180^{\circ}$ & 60 & 45 & 2700 & - & - \\
$1: 1,000,000$ & $6^{\circ} \times 4^{\circ}$ & 2 & 2 & 4 & $2^{\circ} \times 2^{\circ}$ & $(3,2)$ \\
$1: 500,000$ & $3^{\circ} \times 2^{\circ}$ & 2 & 2 & 4 & $1^{\circ} \times 1^{\circ}$ & $(3,2)$ \\
$1: 250,000$ & $1^{\circ} 30^{\prime} \times 1^{\circ}$ & 3 & 3 & 9 & $30^{\prime} \times 30^{\prime}$ & $(3,2)$ \\
$1: 100,000$ & $30^{\prime} \times 20^{\prime}$ & 2 & 2 & 4 & $10^{\prime} \times 10^{\prime}$ & $(3,2)$ \\
$1: 50,000$ & $15^{\prime} \times 10^{\prime}$ & 2 & 2 & 4 & $5^{\prime} \times 5^{\prime}$ & $(3,2)$ \\
$1: 25,000$ & $7^{\prime} 30^{\prime \prime} \times 5^{\prime}$ & 2 & 2 & 4 & $30^{\prime \prime} \times 30^{\prime \prime}$ & $(15,10)$ \\
$1: 10,000$ & $3^{\prime} 45^{\prime \prime} \times 2^{\prime} 30^{\prime \prime}$ & 2 & 2 & 4 & $5^{\prime \prime} \times 5^{\prime \prime}$ & $(45,30)$ \\
$1: 5,000$ & $1^{\prime} 52.5^{\prime \prime} \times 1^{\prime} 15^{\prime \prime}$ & - & - & - & $0.5^{\prime \prime} \times 0.5^{\prime \prime}$ & $(225,150)$ \\
\hline
\end{tabular}

* According to the division norms of the national basic scale for map sheets, a 1:1,000,000 map sheet is divided into 44 bands between c. $88^{\circ} \mathrm{S}-88^{\circ} \mathrm{N}$ and the two poles are treated separately. Subsequently, mapping the whole globe onto a 1:1,000,000 map sheet will predominantly use the method of equal intervals and the remaining levels will use the equally divided method.

These eight grids can satisfy step two and are integer multiples of $1^{\circ}, 1^{\prime}$ and $1^{\prime \prime}$. However, five of the grids, $30^{\prime}, 10^{\prime}, 5^{\prime}, 30^{\prime \prime}$ and $5^{\prime \prime}$, do not satisfy the criterion stated in step three because they are not the $2^{n}$ multiples of $1^{\circ}, 1^{\prime}$ and $1^{\prime \prime}$, and must therefore be decomposed. By factorizing the span of the five grids and finding the greatest common denominator with the $2^{n}$ multiples of $1^{\circ}, 1^{\prime}$ and $1^{\prime \prime}$, the four basic grids, $2^{\prime}, 1^{\prime}, 2^{\prime \prime}$ and $1^{\prime \prime}$, can be aggregated into five grids, $30^{\prime}, 10^{\prime}, 5^{\prime}, 30^{\prime \prime}$ and $5^{\prime \prime}$, representing the largest grids that fulfill the criterion. Therefore, seven basic grids, $2^{\circ}, 1^{\circ}, 30^{\prime}, 10^{\prime}, 5^{\prime}, 30^{\prime \prime}, 5^{\prime \prime}$ and $0.5^{\prime \prime}$, can form the Chinese national basic scale for map sheets, as shown in Table 2. 
Table 2. Chinese national basic scale for map grid aggregation.

\begin{tabular}{ccccc}
\hline \multicolumn{2}{c}{ National Basic Scale Map Range } & Standard Scale & $\begin{array}{c}\text { Inclusion Condition } \\
\text { for Basic Grids }\end{array}$ \\
\hline & $\begin{array}{c}\text { Difference in } \\
\text { longitude }\end{array}$ & $\begin{array}{c}\text { Difference in } \\
\text { latitude }\end{array}$ & & \\
\cline { 2 - 5 } & $6^{\circ}$ & $4^{\circ}$ & $1: 1,000,000$ & $3 \times 2=62^{\circ}$ grids \\
Exclusion & $3^{\circ}$ & $2^{\circ}$ & $1: 500,000$ & $3 \times 2=61^{\circ}$ grids \\
condition for & $1^{\circ} 30^{\prime}$ & $1^{\circ}$ & $1: 250,000$ & $45 \times 30=13502^{\prime}$ grids \\
combined map & $30^{\prime}$ & $20^{\prime}$ & $1: 100,000$ & $15 \times 10=1502^{\prime}$ grids \\
& $15^{\prime}$ & $10^{\prime}$ & $1: 50,000$ & $15 \times 10=1501^{\prime}$ grids \\
& $7^{\prime} 30^{\prime \prime}$ & $5^{\prime}$ & $1: 25,000$ & $225 \times 150=33,7502^{\prime \prime}$ grids \\
& $3^{\prime} 45^{\prime \prime}$ & $2^{\prime} 30^{\prime \prime}$ & $1: 10,000$ & $225 \times 150=33,7501^{\prime \prime}$ grids \\
$1^{\prime} 52.5^{\prime \prime}$ & $1^{\prime} 15^{\prime \prime}$ & $1: 5,000$ & $225 \times 150=33,7500.5^{\prime \prime}$ grids \\
\hline
\end{tabular}

Similarly, for the latitude and longitude grids system of the Chinese national geographic grids [5], $10^{\circ}, 1^{\circ}, 10^{\prime}, 1^{\prime}, 10^{\prime \prime}$ and $1^{\prime \prime}$ are the five largest basic grids (Table 3 ), but three grids, $10^{\circ}, 10^{\prime}$ and $10^{\prime \prime}$, do not satisfy the criterion of being $2^{n}$ multiples of $1^{\circ}, 1^{\prime}$ and $1^{\prime \prime}$, and can be formed by aggregating the three basic grids, $2^{\circ}, 2^{\prime}$ and $2^{\prime \prime}$ (Table 4). Therefore, seven grids, $2^{\circ}, 1^{\circ}, 2^{\prime}, 1^{\prime}, 2^{\prime \prime}, 1^{\prime \prime}$ and $0.5^{\prime \prime}$, can be aggregated to form the latitude and longitude grid system of the Chinese national geographic grids.

Table 3. Latitude and longitude grid analysis for the Chinese national geographic grid.

\begin{tabular}{ccccccc}
\hline Level & Size of Grid & $\begin{array}{c}\text { Frequency of } \\
\text { Longitude }(\boldsymbol{m})\end{array}$ & $\begin{array}{c}\text { Frequency of } \\
\text { Latitude }(\boldsymbol{m})\end{array}$ & Aperture & $\boldsymbol{R}_{\text {Basic }}$ & $\left(\boldsymbol{n}_{\text {lat }}, \boldsymbol{n}_{\text {long }}\right)$ \\
\hline 0 & $360^{\circ} \times 180^{\circ}$ & 36 & 18 & 648 & - & - \\
1 & $10^{\circ} \times 10^{\circ}$ & 10 & 10 & 100 & $10^{\circ} \times 10^{\circ}$ & $(1,1)$ \\
2 & $1^{\circ} \times 1^{\circ}$ & 6 & 6 & 36 & $1^{\circ} \times 1^{\circ}$ & $(1,1)$ \\
3 & $10^{\prime} \times 10^{\prime}$ & 10 & 10 & 100 & $10^{\prime} \times 10^{\prime}$ & $(1,1)$ \\
4 & $1^{\prime} \times 1^{\prime}$ & 6 & 6 & 36 & $1^{\prime} \times 1^{\prime}$ & $(1,1)$ \\
5 & $10^{\prime \prime} \times 10^{\prime \prime}$ & 10 & 10 & 100 & $10^{\prime \prime} \times 10^{\prime \prime}$ & $(1,1)$ \\
6 & $1^{\prime \prime} \times 1^{\prime \prime}$ & - & - & - & $1^{\prime \prime} \times 1^{\prime \prime}$ & $(1,1)$ \\
\hline
\end{tabular}

Table 4. Aggregation of the Chinese national geographic (latitude and longitude) grid.

\begin{tabular}{ccc}
\hline \multicolumn{2}{c}{ National Geographic Grid } & \multirow{2}{*}{ Inclusion Condition for Basic Grids } \\
\cline { 1 - 2 } Difference in Latitude & Difference in Longitude & \\
\hline $10^{\circ}$ & $10^{\circ}$ & $5 \times 5=252^{\circ}$ grids \\
$1^{\circ}$ & $1^{\circ}$ & $1 \times 1=11^{\circ}$ grids \\
$10^{\prime}$ & $10^{\prime}$ & $5 \times 5=252^{\prime}$ grids \\
$1^{\prime}$ & $1^{\prime}$ & $1 \times 1=11^{\prime}$ grids \\
$10^{\prime \prime}$ & $10^{\prime \prime}$ & $5 \times 5=252^{\prime \prime}$ grids \\
$1^{\prime \prime}$ & $1^{\prime \prime}$ & $1 \times 1=1$ of $1^{\prime \prime}$ grids \\
\hline
\end{tabular}

Additionally, we analyzed other subdivision grids and framing standards, including the American USNG, the Canadian NTS, and aviation map framing standards from Canada, Australia, India, the former Soviet Union, and other sources. We found that $4^{\circ}, 2^{\circ}, 1^{\circ}, 2^{\prime}, 1^{\prime}, 2^{\prime \prime}, 1^{\prime \prime}$ and $0.5^{\prime \prime}$ are the eight basic grids used to form typical latitude and longitude grid systems such as national geographic grids, foreign mapping map sheets, and aviation maps.

Thus, the constraints for a consistent latitude and longitude grid model design are:

(1) use CGCS2000 as the basis for geospace;

(2) inherit historical data where possible;

(3) grid codes must be suitable for computer processing and convenient for human identification; 
(4) apply geodetic theory and technological systems comprehensively to spatial information organization and geographic object orientation;

(5) include the eight basic grids, $4^{\circ}, 2^{\circ}, 1^{\circ}, 2^{\prime}, 1^{\prime}, 2^{\prime \prime}, 1^{\prime \prime}$ and $0.5^{\prime \prime}$; and

(6) the existing grids based on latitude and longitudes.

According to the above analysis of the consistent latitude and longitude grid model for Earth's surface, the subdivision system is defined as $\left\{\mathrm{E}, \mathrm{S}_{0}, \mathrm{~S}_{1}, \ldots, \mathrm{S}_{32}\right\}$. The interval of latitudes and longitudes Ri expands up to $512^{\circ}$, i.e., $\left(2^{9}\right)^{\circ}$, on the basis of the eight basic grids, and four levels are inserted in between $1^{\circ}$ and $2^{\prime}$ as well as $1^{\prime}$ and $2^{\prime \prime}$; grids $0.5^{\prime \prime}$ below are expanded down to $1 / 2048^{\prime}$. The interval $\mathrm{Ri}$ establishes the latitude and longitude grid, and $\mathrm{E}$ is the expanded geospace: the whole space is expanded to $512^{\circ} \times 512^{\circ}$, each degree space is expanded to $64^{\prime} \times 64^{\prime}$, and each minute space expanded to $64^{\prime \prime} \times 64^{\prime \prime}$. This defines the subdivision system of a consistent latitude and longitude grid for Earth's surface. In essence, it is a latitude and longitude grid with equal intervals and aperture four.

\section{Geographical Coordinate Global Subdividing Grid with One Dimension Integer Coding on a $2^{\text {n }}$ Tree (GeoSOT)}

\subsection{GeoSOT Subdivision}

The GeoSOT (Geographical coordinate Subdividing grid with One dimension integer coding on a $2^{\mathrm{n}}$ Tree) proposed for this study is a geospace reference grid.

Through dividing the Earth three times (expand the earth $\left(180^{\circ} \times 360^{\circ}\right)$ into $512^{\circ} \times 512^{\circ}$, then each $1^{\circ}$ expand into $64^{\prime}$ and each $1^{\prime}$ expand into $64^{\prime \prime}$, see Figure 3 ), quadtree subdivisions at the degree, minute, and second levels are obtained and the GeoSOT is congruent and aligned; the largest subdivision cell in the highest level (Level 0) can represent the whole Earth's surface, while the smallest subdivision cell in the lowest level (Level 32) can represent centimeter scales. The eight basic grids of $4^{\circ}, 2^{\circ}, 1^{\circ}, 2^{\prime}, 1^{\prime}, 2^{\prime \prime}, 1^{\prime \prime}$ and $0.5^{\prime \prime}$ are also included.

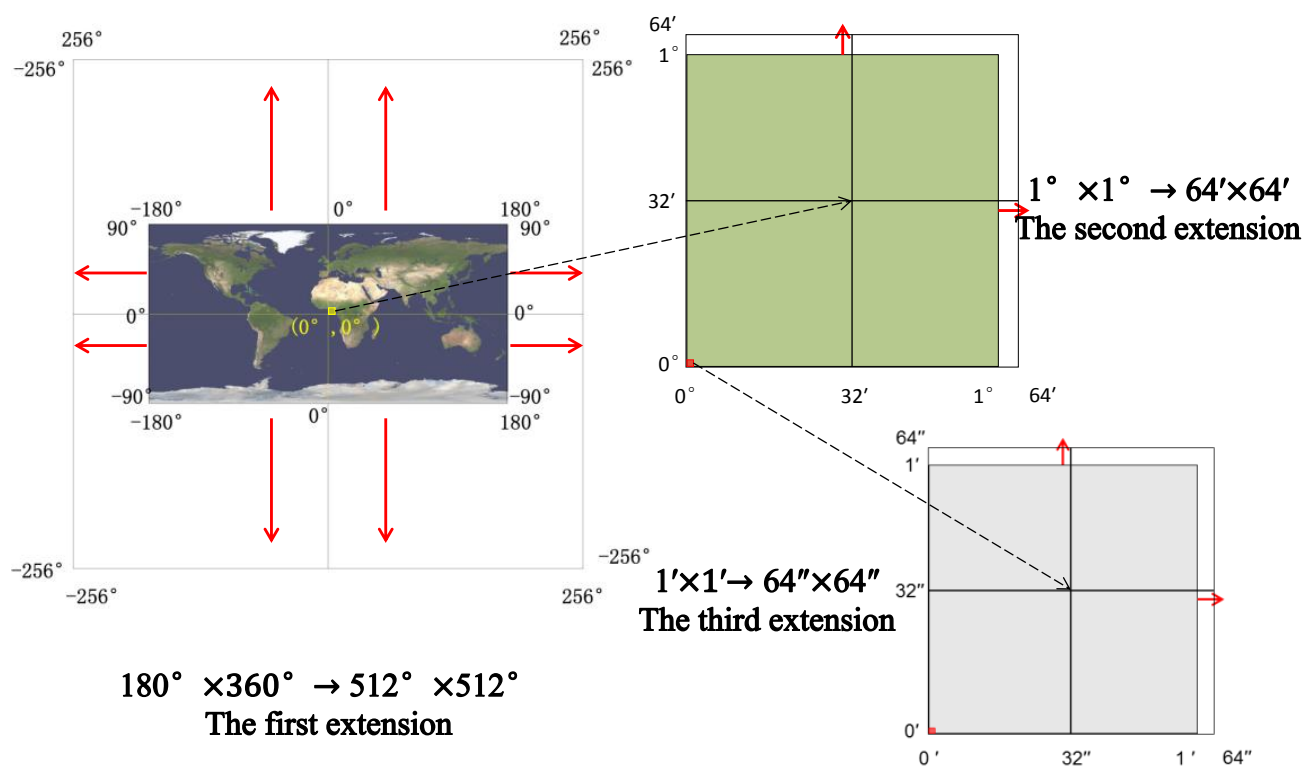

Figure 3. The three main divisions of the GeoSOT (Geographical coordinate Subdividing grid with One dimension integer coding on a $2^{\text {n }}$ Tree) subdivision.

GeoSOT involves 32 levels and the origin is the intersection of the prime meridian and the equator. The latitudes are formed by lines with equal lengths at equal intervals, while longitude lines of equal lengths are perpendicular to latitudes at equal intervals. The ratio of longitude to latitude length is 1:2. 
The North and South Poles are parallel to latitudes and equal in length. The ranges of latitude and longitude are $180^{\circ}$ and $360^{\circ}$, respectively.

Level 0 is defined as the $512^{\circ} \times 512^{\circ}$ grid where the center point and the origin coincide in geographical coordinate space. Its grid code is " $G$ ", (signifying "Globe") and the regional location is the whole global area.

Level 1 is defined as the four cells $\left(256^{\circ} \times 256^{\circ}\right.$ each) equally divided over Level 0 its grid code is "Gd", where " $\mathrm{d}$ " stands for $0,1,2$, or 3. For example, the regional location of G0 is the Northeast Hemisphere region.

Following this logic, Level 2 is obtained by quadtree division of Level 1, and so on up to Level 9. Levels 1-9 are each termed GeoSOT degree-level grids.

Levels 10-15 are rooted in the minute-level grid (Level 9, $1^{\circ} \times 1^{\circ}$ grid or $60^{\prime} \times 60^{\prime}$ grid), and they have the same codes. The grid size is extended from $60^{\prime}$ to $64^{\prime}$. GeoSOT subdivision grids are obtained by performing quadtree divisions of the extended Level 9 grid.

Levels 16-21 are rooted in the second-level grid (Level 15, $1^{\prime} \times 1^{\prime}$ grid or $60^{\prime \prime} \times 60^{\prime \prime}$ grid), and they have the same codes. The grid size is extended from $60^{\prime \prime}$ to $64^{\prime \prime}$. GeoSOT subdivision grids are obtained by performing quadtree divisions of the extended Level 15 grid.

Grids smaller than a second (levels 22-32) can be obtained by dividing the previous level into four equal cells.

According to the above definitions, GeoSOT grids are divided into 32 levels, with the greatest covering the entire global space and the smallest at the centimeter-level. These 32 levels divide Earth's surface evenly into multi-leveled grids that form the global quadtree system (Figure 4). The ratio of the upper to the lower levels is approximately $4: 1$ and the change is uniform.

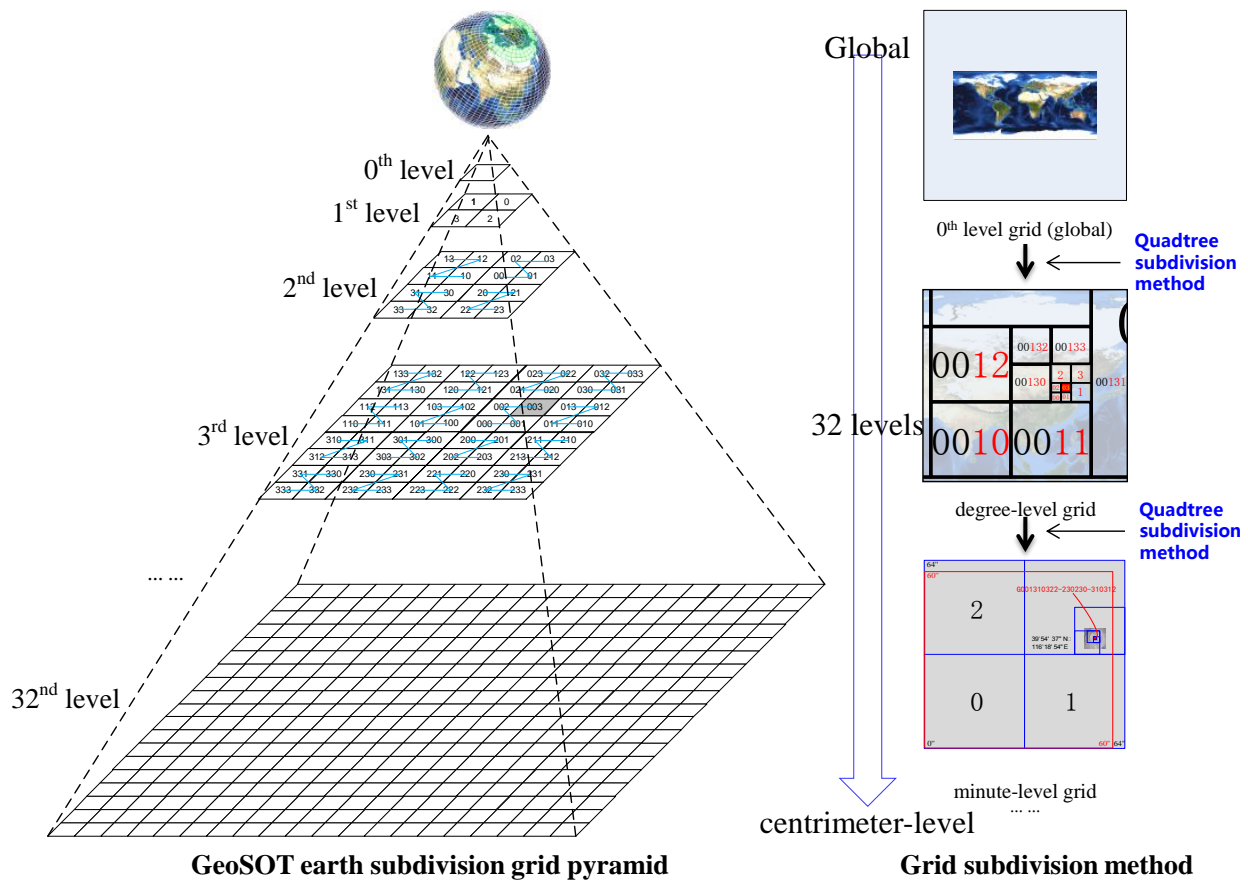

Figure 4. The global $2^{\mathrm{n}}$ integer quadtree subdivision after extending latitude and longitude three times.

For the polar regions, Level 6, which forms an $8^{\circ} \times 2^{\circ}$ grid at the poles, regards the whole South (North) Pole region as a unit (i.e., as a $360^{\circ} \times 2^{\circ}$ grid). The poles belong to Level 6 and the area between longitude $8^{\circ} \mathrm{E}$ and the prime meridian in the original $8^{\circ} \times 2^{\circ}$ grid is represented by the grid code $\mathrm{P}$. To ensure the grid is divided evenly, there is no subdivision at Level 7. Instead, subdivision begins at Level 8, and the GeoSOT polar region subdivision grid is formed by dividing each previous level into four parts as follows (Figure 5): 
(1) Divide the polar circles into two parts according to the hypothetical extension rule: on reaching the $1^{\circ}$ level, extend from $1^{\circ}$ to $64^{\prime}$ before dividing the polar circles.

(2) Define the inner circle where the poles are located as P0, and divide the outer circle into three parts along the prime meridian, longitude $120^{\circ} \mathrm{E}$, and longitude $120^{\circ} \mathrm{W}$. These parts are P1, P2 and P3, respectively, and form four cells together with P0. These four cells are almost equal in size.

(3) From P1, P2 and P3, continue quadtree division, using a similar rule as for the GeoSOT: dividing after extending from $120^{\circ}$ to $128^{\circ}$.

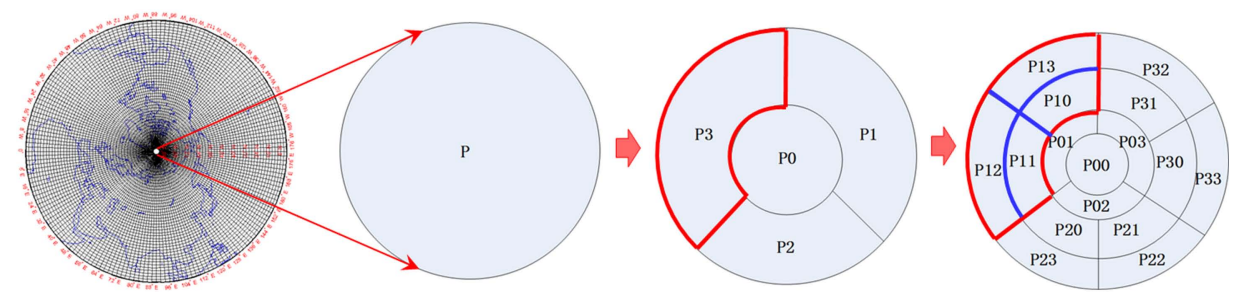

Figure 5. GeoSOT polar region grid subdivision method.

\subsection{GeoSOT Grid and the Shape on a Sphere}

We can calculate the possible shapes and differences of GeoSOT subdivisions on Earth's surface, as shown in Table 5. Table 6 shows the basic situation for the polar region grid. Table 7 summarizes GeoSOT for the whole global region.

Table 5. The possible different shapes of GeoSOT on Earth's surface.

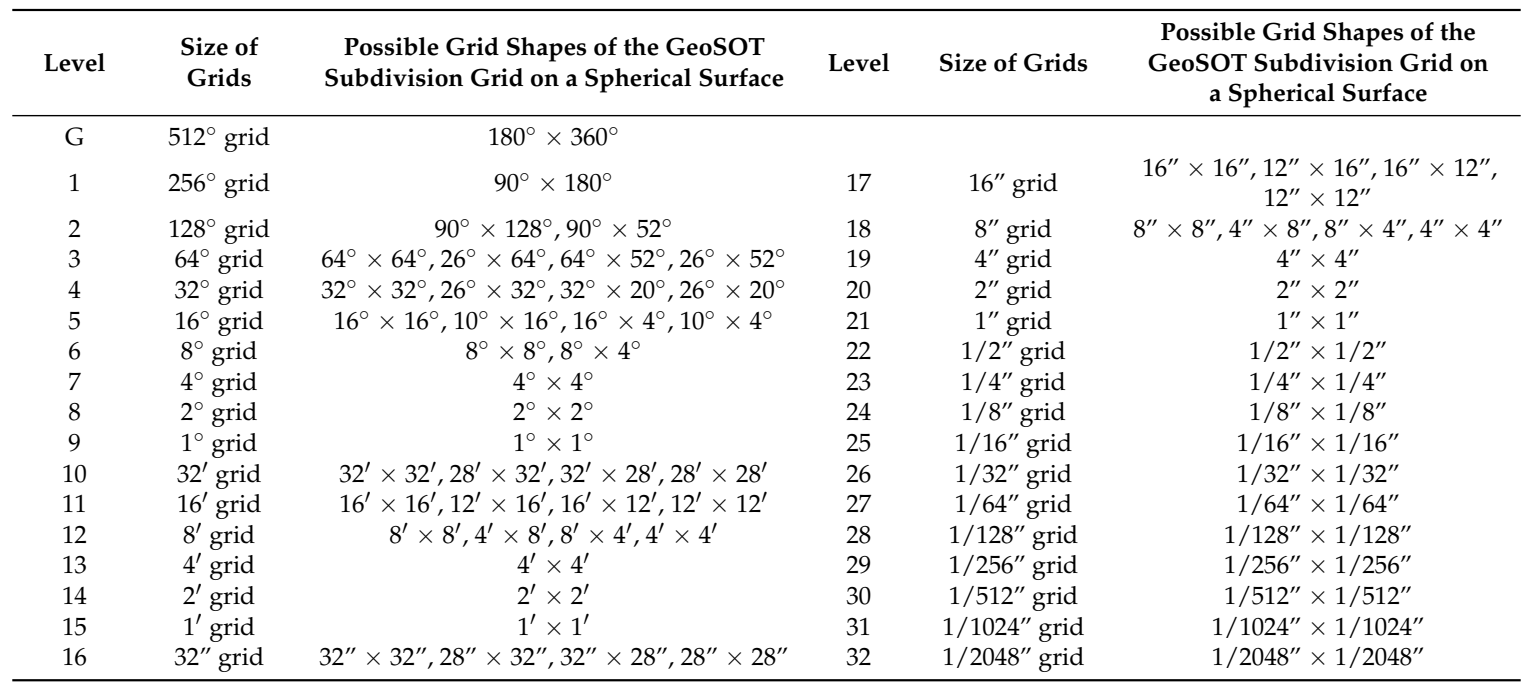

Table 6. Situation of the polar region grids.

\begin{tabular}{ccc}
\hline Level & Size of Grid & $\begin{array}{r}\text { Possible Grid Shapes of the Subdivision Grid on a } \\
\text { Sphere (Except for the Polar Point Cells) }\end{array}$ \\
\hline 8 & $128^{\circ} \times 1^{\circ}$ & $120^{\circ} \times 1^{\circ}$ \\
9 & $64^{\circ} \times 32^{\prime}$ & $64^{\circ} \times 32^{\prime}, 56^{\circ} \times 32^{\prime}, 64^{\circ} \times 28^{\prime}, 56^{\circ} \times 28^{\prime}$ \\
10 & $32^{\circ} \times 16^{\prime}$ & $32^{\circ} \times 16^{\prime}, 24^{\circ} \times 16^{\prime}, 32^{\circ} \times 12^{\prime}, 24^{\circ} \times 12^{\prime}$ \\
11 & $16^{\circ} \times 8^{\prime}$ & $16^{\circ} \times 8^{\prime}, 16^{\circ} \times 4^{\prime}, 8^{\circ} \times 8^{\prime}, 8^{\circ} \times 4^{\prime}$ \\
12 & $8^{\circ} \times 4^{\prime}$ & $8^{\circ} \times 4^{\prime}$ \\
13 & $4^{\circ} \times 2^{\prime}$ & $4^{\circ} \times 2^{\prime}$ \\
14 & $2^{\circ} \times 1^{\prime}$ & $2^{\circ} \times 1^{\prime}$ \\
15 & $1^{\circ} \times 32^{\prime \prime}$ & $1^{\circ} \times 32^{\prime \prime}, 1^{\circ} \times 28^{\prime \prime}$ \\
16 & \multicolumn{2}{c}{ Below this level, rules are as for the GeoSOT grid. } \\
\hline
\end{tabular}


Table 7. Statistics for GeoSOT.

\begin{tabular}{|c|c|c|c|c|c|c|c|}
\hline Level & Grid Size & $\begin{array}{l}\text { Approximate Dimension } \\
\text { Near the Equator }\end{array}$ & Quantity & Level & Grid Size & $\begin{array}{l}\text { Approximate Dimension } \\
\text { Near the Equator }\end{array}$ & Quantity \\
\hline G & $512^{\circ}$ specification & Global region & 1 & & & & \\
\hline 1 & $256^{\circ}$ specification & $1 / 4$ global region & 4 & 17 & $16 "$ specification & $512 \mathrm{~m}$ specification & $3,649,536,000$ \\
\hline 2 & $128^{\circ}$ specification & & 8 & 18 & $8 "$ specification & $256 \mathrm{~m}$ specification & $14,598,144,000$ \\
\hline 3 & $64^{\circ}$ specification & & 24 & 19 & 4" specification & $128 \mathrm{~m}$ specification & $51,321,600,000$ \\
\hline 4 & $32^{\circ}$ specification & & 72 & 20 & $2 "$ specification & $64 \mathrm{~m}$ specification & $205,286,400,000$ \\
\hline 5 & $16^{\circ}$ specification & & 288 & 21 & 1" specification & $32 \mathrm{~m}$ specification & $821,145,600,000$ \\
\hline 6 & $8^{\circ}$ specification & $1024 \mathrm{~km}$ specification & 1012 & 22 & $1 / 2^{\prime \prime}$ specification & $16 \mathrm{~m}$ specification & $3,284,582,400,000$ \\
\hline 7 & $4^{\circ}$ specification & $512 \mathrm{~km}$ specification & 3960 & 23 & $1 / 4$ " specification & $8 \mathrm{~m}$ specification & $13,138,329,600,000$ \\
\hline 8 & $2^{\circ}$ specification & $256 \mathrm{~km}$ specification & 15,840 & 24 & $1 / 8^{\prime \prime}$ specification & $4 \mathrm{~m}$ specification & $52,553,318,400,000$ \\
\hline 9 & $1^{\circ}$ specification & $128 \mathrm{~km}$ specification & 63,360 & 25 & $1 / 16^{\prime \prime}$ specification & $2 \mathrm{~m}$ specification & $210,213,273,600,000$ \\
\hline 10 & $32^{\prime}$ specification & $64 \mathrm{~km}$ specification & 253,440 & 26 & $1 / 32$ " specification & $1 \mathrm{~m}$ specification & $840,853,094,400,000$ \\
\hline 11 & $16^{\prime}$ specification & $32 \mathrm{~km}$ specification & 1013,760 & 27 & $1 / 64^{\prime \prime}$ specification & $0.5 \mathrm{~m}$ specification & $3,363,412,377,600,000$ \\
\hline 12 & $8^{\prime}$ specification & $16 \mathrm{~km}$ specification & $4,055,040$ & 28 & $1 / 128^{\prime \prime}$ specification & $25 \mathrm{~cm}$ specification & $13,453,649,510,400,000$ \\
\hline 13 & $4^{\prime}$ specification & $8 \mathrm{~km}$ specification & $14,256,000$ & 29 & $1 / 256^{\prime \prime}$ specification & $12.5 \mathrm{~cm}$ specification & $53,814,598,041,600,000$ \\
\hline 14 & $2^{\prime}$ specification & $4 \mathrm{~km}$ specification & $57,024,000$ & 30 & $1 / 512$ " specification & $6.2 \mathrm{~cm}$ specification & $215,258,392,166,400,000$ \\
\hline 15 & $1^{\prime}$ specification & $2 \mathrm{~km}$ specification & $228,096,000$ & 31 & $1 / 1024$ " specification & $3.1 \mathrm{~cm}$ specification & $861,033,568,665,600,000$ \\
\hline 16 & $32 "$ specification & $1 \mathrm{~km}$ specification & $912,384,000$ & 32 & $1 / 2048$ " specification & $1.5 \mathrm{~cm}$ specification & $3,444,134,274,662,400,000$ \\
\hline
\end{tabular}




\section{Analysis of the Consistency between GeoSOT and Existing Latitude and Longitude Grids}

\subsection{The Principle behind Consistency between GeoSOT and the Latitude and Longitude Grids}

The basis of the consistency between GeoSOT and the latitude and longitude grid is the isomorphism between the two.

Definition 3: If a level of a subdivision grid GA can be aggregated into a different level of GB, then GA and $\mathrm{GB}$ are isomorphic (i.e., $\mathrm{G}_{\mathrm{A}} \simeq \mathrm{G}_{\mathrm{B}}$ ). However, this is not commutative, so $\mathrm{G}_{\mathrm{B}} \simeq \mathrm{G}_{\mathrm{A}}$ may not be true.

For global latitude and longitude grids (G1, G2 and G3), if G1 can be aggregated to become G2 and $\mathrm{G} 2$ to become $\mathrm{G} 3$, then $\mathrm{G} 1$ is isomorphic to $\mathrm{G} 3$ (i.e., $\mathrm{G}_{1} \simeq \mathrm{G}_{2}, \mathrm{G}_{2} \simeq \mathrm{G}_{3} \Rightarrow \mathrm{G}_{1} \simeq \mathrm{G}_{3}$ ). Additionally, any global latitude and longitude grid $\mathrm{G}$ is isomorphic to itself.

Definition 4: For global latitude and longitude grids (G1, G2 and G3), if G1 can be aggregated into G2 and $\mathrm{G} 1$ can be aggregated into $\mathrm{G} 3$ and $\mathrm{G}_{2} \mathrm{G}_{3}$, then $\mathrm{G} 2$ and $\mathrm{G} 3$ are weakly isomorphic (i.e., $\mathrm{G}_{2} \sim \mathrm{G}_{3}$ ).

For GeoSOT grids, suppose the grid cell of the $i^{\text {th }}$ level is $C_{i}=f\left(t_{i}, b_{i}, l_{i}, r_{i}\right)$, since it has undergone three subdivision extensions, the expression can be divided into three parts for treatment. In these three transitions (i.e., from Level 0 to Level 1, from Level 9 to Level 10, and from Level 15 to Level 16) divisions are made at equal intervals from the upper level grid. For other transitions, divisions are obtained by equally dividing the grids. According to Equation (3), the initial values are segmented as follows:

$$
\left\{\begin{array}{c}
\overline{\mathrm{t}_{0}}=\overline{\mathrm{b}_{0}}=\overline{\mathrm{L}_{\mathrm{t}}}=\mathrm{L}_{\mathrm{b}}=512^{\circ}, \overline{\mathrm{l}_{0}}=\overline{\mathrm{r}_{0}}=\mathrm{L}_{\mathrm{l}}=\mathrm{L}_{\mathrm{r}}=512^{\circ} \\
\overline{\mathrm{t}_{10}}=\overline{\mathrm{b}_{10}}=32^{\prime}, \overline{\overline{1}_{10}}=\overline{\mathrm{r}_{10}}=32^{\prime} \\
\overline{\mathrm{t}_{16}}=\overline{\mathrm{b}_{16}}=32^{\prime \prime}, \overline{\mathrm{l}_{16}}=\overline{\mathrm{r}_{16}}=32^{\prime \prime}
\end{array}\right.
$$

Equation (12) shows the difference in subdivision methods:

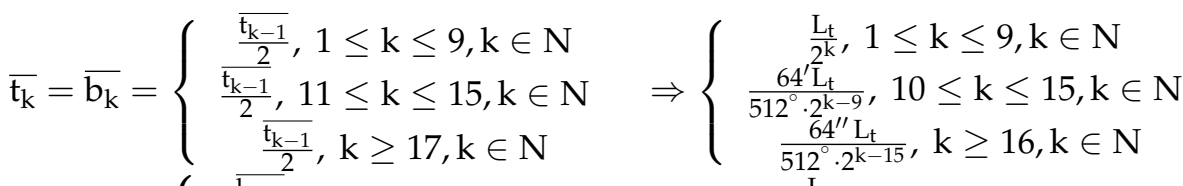

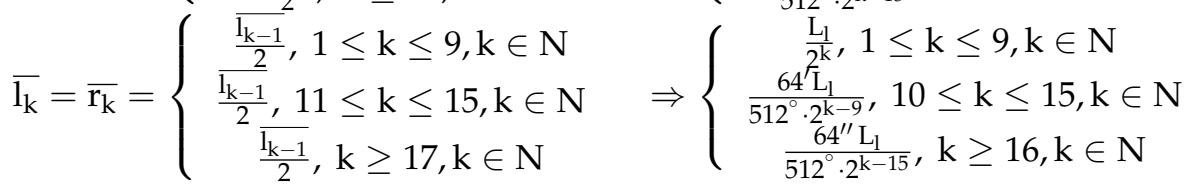

Here, the eight basic grids, $4^{\circ}, 2^{\circ}, 1^{\circ}, 2^{\prime}, 1^{\prime}, 2^{\prime \prime}, 1^{\prime \prime}$ and $0.5^{\prime \prime}$, correspond to levels $7-9,14,15$ and 20-22 (k) in the GeoSOT grid.

\subsection{Analysis of the Isomorphism of GeoSOT with Latitude and Longitude Grids with Absolute Degrees, Minutes, and Seconds}

Latitude and longitude grids with absolute degrees, minutes, and seconds are a special type of grid. They may not be fully hierarchical and can form a single-level latitude and longitude grid, but their fixed points and spans should always be in absolute degrees, minutes, and seconds.

These grids must be described as multiples of 1" grids. According to Equation (1), the 1" grid corresponds to Level 21. Therefore, any grid with absolute degrees, minutes, and seconds can be aggregated from the Level 21 GeoSOT grid. Further aggregation of a complete GeoSOT grid can form the polymerization of other grids with absolute degrees, minutes and seconds. We can therefore conclude that GeoSOT is isomorphic to such grids.

This process essentially uses grids with equal intervals, and is similar to the method used to switch between the various GeoSOT codes described above, as the values for degrees, minutes, and seconds are converted from base ten to binary. Spatial regions involving absolute degrees, minutes, and seconds 
can be represented by GeoSOT when there is no input error. None of the existing grids currently possesses this characteristic.

\subsection{Analysis of the Isomorphism between GeoSOT and Traditional Map Sheet Grids}

The following example of the Chinese national topographic map sheet grid uses the basic scale to confirm the isomorphism between GeoSOT and traditional map sheet grids. Aeronautical maps, sea charts, and meteorological charts are all based on map sheets. They are usually obtained either through extension (for example, aeronautical maps and meteorological charts are both based on 1:1,000,000 map sheets) or through extracting a few levels from standard map sheets. It therefore follows that map sheet grids are isomorphic to other map sheet grids within different industries. Hence, to prove that GeoSOT is isomorphic to these map sheet grids, only one map sheet grid needs to be shown to be isomorphic to GeoSOT.

Let the grid cell in the $i^{\text {th }}$ level of a map sheet grid with basic scale be $C_{i}=f\left(t_{i}, b_{i}, l_{i}, r_{i}\right)$. According to Equation (3), its initial value is:

$$
\mathrm{L}_{\mathrm{t} 0}=\mathrm{L}_{\mathrm{b} 0}=360^{\circ}, \mathrm{L}_{10}=\mathrm{L}_{\mathrm{r} 0}=180^{\circ}
$$

Level 0 (whole globe) to Level 1 (1:1,000,000 subdivided cells) constitutes a grid pattern with equal intervals such that $\mathrm{m}=60, n=45, \Delta \mathrm{t}_{1}=\Delta \mathrm{L}_{1}=6^{\circ}$ and $\Delta \mathrm{l}_{1}=\Delta \mathrm{r}_{1}=4^{\circ}$. From Level 1 to Level 8 (1:5000 cells), cells are divided into equal parts. The difference in subdivision methods can be represented as

$$
\begin{aligned}
& \overline{\mathrm{t}_{\mathrm{k}}}=\overline{\mathrm{b}_{\mathrm{k}}}=\left\{\begin{array}{c}
\frac{\overline{\mathrm{t}_{\mathrm{k}-1}}}{2}, \mathrm{k}=2,3,5,6,7,8 \\
\overline{\frac{\mathrm{t}_{\mathrm{k}-1}}{3}, \mathrm{k}=4}
\end{array}\right. \\
& \overline{\mathrm{l}_{\mathrm{k}}}=\overline{\mathrm{r}_{\mathrm{k}}}=\left\{\begin{array} { l } 
{ \overline { \frac { \mathrm { l } _ { \mathrm { k } - 1 } } { 2 } } , \mathrm { k } = 2 , 3 , 5 , 6 , 7 , 8 } \\
{ \overline { \mathrm { I } _ { \mathrm { k } - 1 } } , \mathrm { k } = 4 }
\end{array} \Rightarrow \left\{\begin{array}{l}
\frac{\Delta \mathrm{t}_{1}}{2^{\mathrm{k}-1}}, 1 \leq \mathrm{k}<4, \mathrm{k} \in \mathrm{N} \\
\frac{\Delta \mathrm{t}_{1}}{3 \cdot 2^{\mathrm{k}-2}}, 4 \leq \mathrm{k} \leq 8, \mathrm{k} \in \mathrm{N}
\end{array}\right.\right.
\end{aligned}
$$

The following section provides a proof of their isomorphism.

If, in the $\mathrm{t}$ - and $\mathrm{b}$-directions, the basic scale topographic map sheet grid on the $\mathrm{k}^{\text {th }}$ level can be aggregated by the GeoSOT grid on the $\mathrm{k}^{\text {th }}$ level, the two grids must satisfy the relationship stated in Equation (8). Using Equations (12) and (13), Equation (15) is obtained:

$$
\begin{aligned}
& \left\{\begin{array}{c}
\frac{\Delta \mathrm{t}_{1}}{2^{\mathrm{k}-1}}=\mathrm{X} \cdot \frac{\mathrm{L}_{\mathrm{t}}}{2^{\mathrm{k} 1}}, \mathrm{k} \leq 2, \mathrm{k} \in \mathrm{N}^{+} \\
\frac{\Delta \mathrm{t}_{1}}{2^{\mathrm{k}-1}}=\mathrm{X} \cdot \frac{64^{\prime} \mathrm{L}_{\mathrm{t}}}{512^{\circ} \cdot 2^{\mathrm{k}}}, \mathrm{k}=3 \\
\frac{\Delta \mathrm{t}_{1}}{3 \cdot 2^{\mathrm{k}-2}}=\mathrm{X} \cdot \frac{64^{\prime} \mathrm{L}_{\mathrm{t}} \cdot 2^{\mathrm{k} 1-9}}{512^{\mathrm{k}}{ }^{\mathrm{k} 1-9}}, 4 \leq \mathrm{k} \leq 5, \mathrm{k} \in \mathrm{N} \\
\frac{\Delta \mathrm{t}_{1}}{3 \cdot 2^{\mathrm{k}-2}}=\mathrm{X} \cdot \frac{64^{\prime \prime} \mathrm{L}_{t}}{512^{\circ} \cdot 2^{\mathrm{k} 1-15}}, 6 \leq \mathrm{k} \leq 8, \mathrm{k} \in \mathrm{N}
\end{array}\right. \\
& \Rightarrow\left\{\begin{array}{c}
X=2^{k 1-k+1} \frac{\Delta t_{1}}{L_{t}}, k \leq 2, k \in N^{+} \\
X=2^{k 1-k-8} \frac{\Delta t_{1}}{64^{\prime}}, k=3 \\
X=\frac{2^{k 1-k-7}}{3} \cdot \frac{\Delta t_{1}}{64^{\prime}}, 4 \leq k \leq 5, k \in N \\
X=\frac{2^{k 1-k-13}}{3} \cdot \frac{\Delta t_{1}}{64^{\prime \prime}}, 6 \leq k \leq 8, k \in N
\end{array}\right.
\end{aligned}
$$

Satisfying Equation (15) and $\forall \mathrm{k} \in[1,8], \mathrm{k} \in \mathrm{N}, \exists \mathrm{k} 1 \in[1,32] \cap \mathrm{k} 1 \in \mathrm{N}, \mathrm{X} \in \mathrm{N}^{+}$will constitute proof of isomorphism. The conditions of isomorphism are as follows:

(1) Equation (15-1): $\Delta \mathrm{t}_{1}=6^{\circ}, \mathrm{L}_{\mathrm{t}}=512^{\circ} \rightarrow \mathrm{X}=3 \cdot 2^{\mathrm{k} 1-\mathrm{k}-7}$. To satisfy $\mathrm{X} \in \mathrm{N}^{+}, \mathrm{k} 1 \geq \mathrm{k}+7$ must be true. For the lowest level, $\mathrm{k} 1=\mathrm{k}+7$, where $\mathrm{k} \leq 2, \mathrm{k} \in \mathrm{N}^{+}$;

(2) Equation (15-2): $\Delta \mathrm{t}_{1}=6^{\circ} \rightarrow \mathrm{X}=360 \cdot 2^{\mathrm{k} 1-\mathrm{k}-14}=45 \cdot 2^{\mathrm{k} 1-\mathrm{k}-11}$. To satisfy $\mathrm{X} \in \mathrm{N}^{+}, \mathrm{k} 1 \geq \mathrm{k}+11$ must be true. For the lowest level, $\mathrm{k} 1=\mathrm{k}+11$, where $\mathrm{k}=3$; 
(3) Equation (15-3): $\Delta \mathrm{t}_{1}=6^{\circ} \rightarrow \mathrm{X}=120 \cdot 2^{\mathrm{k} 1-\mathrm{k}-13}=15 \cdot 2^{\mathrm{k} 1-\mathrm{k}-10}$. To satisfy $\mathrm{X} \in \mathrm{N}^{+}, \mathrm{k} 1 \geq \mathrm{k}+10$ must be true. For the lowest level, $\mathrm{k} 1=\mathrm{k}+10$, where $4 \leq \mathrm{k} \leq 5, \mathrm{k} \in \mathrm{N}$;

(4) Equation (15-4): $\Delta \mathrm{t}_{1}=6^{\circ} \rightarrow \mathrm{X}=7200 \cdot 2^{\mathrm{k} 1-\mathrm{k}-19}=225 \cdot 2^{\mathrm{k} 1-\mathrm{k}-14}$. To satisfy $\mathrm{X} \in \mathrm{N}^{+}, \mathrm{k} 1 \geq \mathrm{k}+14$ must be true. For the lowest level, $\mathrm{k} 1=\mathrm{k}+14$, where $6 \leq \mathrm{k} \leq 8, \mathrm{k} \in \mathrm{N}$.

The directions of 1 and $\mathrm{r}$ are similar. The same method can be used to calculate the corresponding level $\mathrm{k} 2$ for GeoSOT. The final $\mathrm{k}^{\text {th }}$ level of a basic-scale topographic map sheet grid can be aggregated from the $\mathrm{k}^{\mathrm{th}}$ level of GeoSOT, where $\mathrm{k} 0=\max (\mathrm{k} 1, \mathrm{k} 2)$. The results in Table 8 were obtained according to this conclusion.

Table 8. Analysis of the isomorphism between GeoSOT and basic-scale topographic map sheet grids.

\begin{tabular}{cccccc}
\hline $\mathbf{k}$ & $\mathbf{k 1}$ & $\mathbf{X}$ & $\mathbf{k} \mathbf{2}$ & $\mathbf{Y}$ & $\mathbf{k 0}$ \\
\hline 1 & 8 & 3 & 8 & 2 & 8 \\
2 & 9 & 3 & 9 & 2 & 9 \\
3 & 14 & 45 & 14 & 30 & 14 \\
4 & 14 & 15 & 14 & 10 & 14 \\
5 & 15 & 15 & 15 & 10 & 15 \\
6 & 20 & 225 & 20 & 150 & 20 \\
7 & 21 & 225 & 21 & 150 & 21 \\
8 & 22 & 225 & 22 & 150 & 22 \\
\hline
\end{tabular}

From Table 8, it is clear that topographic map sheet grids of different scales can be obtained by aggregating the seven basic grids: Level $8\left(2^{\circ}\right)$, Level $9\left(1^{\circ}\right)$, Level $14\left(2^{\prime}\right)$, Level $15\left(1^{\prime}\right)$, Level $20\left(2^{\prime \prime}\right)$, Level 21 (1") and Level $22\left(0.5^{\prime \prime}\right)$. The results of aggregation are similar to those displayed in Table 2, and show that GeoSOT is isomorphic to the basic-scale Chinese national topographic map sheet grid, and also isomorphic to professional map sheet grids such as aeronautical maps, meteorological charts, sea charts, etc.

\subsection{Analysis of the Isomorphism between GeoSOT and Existing Digital Earth Grids}

The example of NASA's World Wind digital Earth grid is considered below to demonstrate that GeoSOT is isomorphic to existing digital Earth grids. Table 9 shows the subdivision method for the World Wind digital Earth grid.

Table 9. Subdivision method for the World Wind digital Earth grid.

\begin{tabular}{ccc}
\hline Level & Grid Size & Grid Number \\
\hline 0 & $360^{\circ} \times 180^{\circ}$ & 1 \\
1 & $36^{\circ} \times 36^{\circ}$ & $10 \times 5$ \\
2 & $18^{\circ} \times 18^{\circ}$ & $20 \times 10$ \\
3 & $9^{\circ} \times 9^{\circ}$ & $40 \times 20$ \\
4 & $4^{\circ} 30^{\prime} \times 4^{\circ} 30^{\prime}$ & $80 \times 40$ \\
5 & $2^{\circ} 15^{\prime} \times 2^{\circ} 15^{\prime}$ & $160 \times 80$ \\
6 & $1^{\circ} 7^{\prime} 30^{\prime \prime} \times 1^{\circ} 7^{\prime} 30^{\prime \prime}$ & $320 \times 160$ \\
7 & $33^{\prime} 45^{\prime \prime} \times 33^{\prime} 45^{\prime \prime}$ & $640 \times 320$ \\
8 & $16^{\prime} 52.5^{\prime \prime} \times 16^{\prime} 52.5^{\prime \prime}$ & $1280 \times 640$ \\
9 & $8^{\prime} 26.25^{\prime \prime} \times 8^{\prime} 26.25^{\prime \prime}$ & $2560 \times 1280$ \\
$\ldots$ & $\ldots$ & $\cdots$ \\
\hline
\end{tabular}

The World Wind digital Earth grid is divided using equal subdivisions. Apart from Level 0, the subdivision frequency for all levels in both latitude and longitude directions is two, and the subdivision aperture is four. According to Equation (3), its initial value is:

$$
\overline{\mathrm{t}_{0}}=\overline{\mathrm{b}_{0}}=360^{\circ}, \overline{\mathrm{l}_{0}}=\overline{\mathrm{r}_{0}}=180^{\circ}
$$


Equation (17) shows the subdivision relationship:

$$
\begin{aligned}
& \overline{\mathrm{t}_{\mathrm{k}}}=\overline{\mathrm{b}_{\mathrm{k}}}=\left\{\begin{array}{c}
\frac{\overline{\mathrm{t}_{\mathrm{k}-1}}}{10}, \mathrm{k}=1 \\
\frac{\mathrm{t}_{\mathrm{k}-1}}{2}, \mathrm{k}>1, \mathrm{k} \in \mathrm{N}
\end{array} \Rightarrow \overline{\mathrm{t}_{\mathrm{k}}}=\overline{\mathrm{b}_{\mathrm{k}}}=\frac{\overline{\mathrm{t}_{0}}}{10 \cdot 2^{\mathrm{k}-1}}, \mathrm{k} \in \mathrm{N}^{+}\right. \\
& \overline{\mathrm{l}_{\mathrm{k}}}=\overline{\mathrm{r}_{\mathrm{k}}}=\left\{\begin{array}{c}
\frac{\overline{\mathrm{l}_{-1}}}{5}, \mathrm{k}=1 \\
\overline{\overline{\mathrm{l}}_{\mathrm{k}-1}}, \mathrm{k}>1, \mathrm{k} \in \mathrm{N}
\end{array} \Rightarrow \overline{\mathrm{l}_{\mathrm{k}}}=\overline{\mathrm{r}_{\mathrm{k}}}=\frac{\overline{\mathrm{l}_{0}}}{5 \cdot 2^{\mathrm{k}-1}}, \mathrm{k} \in \mathrm{N}^{+}\right.
\end{aligned}
$$

If, in the $\mathrm{t}$ - and $\mathrm{b}$-directions, the $\mathrm{k}^{\text {th }}$ level of the World Wind digital Earth grid can be obtained by aggregating the $k 1^{\text {th }}$ level of the GeoSOT grid, the two grids must satisfy Equation (9). Equation (18) can be obtained from Equations (12) and (17):

$$
\left\{\begin{array} { c } 
{ \frac { \overline { \mathrm { t } _ { 0 } } } { 1 0 \cdot 2 ^ { \mathrm { k } - 1 } } = \mathrm { X } \cdot \frac { \mathrm { L } _ { \mathrm { t } } } { 2 ^ { \mathrm { k } 1 } } } \\
{ \frac { 4 _ { \mathrm { t } _ { 0 } } } { 1 0 \cdot 2 ^ { \mathrm { k } - 1 } } = \mathrm { X } \cdot \frac { 6 4 ^ { \prime } \mathrm { L } _ { \mathrm { t } } } { 5 1 2 ^ { \circ } \cdot 2 ^ { \mathrm { k } 1 - 9 } } } \\
{ \frac { \mathrm { t } _ { 0 } } { 1 0 \cdot 2 ^ { \mathrm { k } - 1 } } = \mathrm { X } \cdot \frac { 6 4 ^ { \prime \prime } \mathrm { L } } { 5 1 2 ^ { \circ } \cdot 2 ^ { \mathrm { k } 1 - 1 5 } } }
\end{array} \quad \Rightarrow \left\{\begin{array}{c}
\mathrm{X}=\frac{2^{\mathrm{k} 1-\mathrm{k}+1}}{10} \cdot \frac{\overline{\mathrm{t}_{0}}}{\mathrm{~L}_{\mathrm{t}}}, 1 \leq \mathrm{k} 1 \leq 9, \mathrm{k}, \mathrm{k} 1 \in \mathrm{N} \\
\mathrm{X}=\frac{2^{\mathrm{k} 1-\mathrm{k}-8}}{10} \cdot \frac{\overline{\mathrm{t}}_{0}}{66^{\prime}}, 10 \leq \mathrm{k} 1 \leq 15, \mathrm{k}, \mathrm{k} 1 \in \mathrm{N} \\
\mathrm{X}=\frac{2^{\mathrm{k} 1-\mathrm{k}-14}}{10} \cdot \frac{\overline{\mathrm{t}}_{0}}{64^{\prime \prime}}, \mathrm{k} 1 \geq 16, \mathrm{k}, \mathrm{k} 1 \in \mathrm{N}
\end{array}\right.\right.
$$

Satisfying Equation (18) and $\forall \mathrm{k} \in \mathrm{N}, \exists \mathrm{k} 1 \in \mathrm{N}^{+}, \mathrm{X} \in \mathrm{N}^{+}$will constitute proof of isomorphism. The conditions for the proof of isomorphism are listed below:

(1) Equation (18-1): $\overline{\mathrm{t}_{0}}=360^{\circ}, \mathrm{L}_{\mathrm{t}}=512^{\circ} \rightarrow \mathrm{X}=9 \cdot 2^{\mathrm{k} 1-\mathrm{k}-6}$. To satisfy $\mathrm{X} \in \mathrm{N}^{+}, \mathrm{k} 1 \geq \mathrm{k}+6$ must be true. For the lowest level, $\mathrm{k} 1=\mathrm{k}+6$, where $1 \leq \mathrm{k} 1 \leq 9, \mathrm{k}, \mathrm{k} 1 \in \mathrm{N}^{+}$;

(2) Equation (18-2): $\overline{\mathrm{t}}_{0}=360^{\circ} \rightarrow \mathrm{X}=135 \cdot 2^{\mathrm{k} 1-\mathrm{k}-10}$. To satisfy $\mathrm{X} \in \mathrm{N}^{+} \mathrm{k} 1 \geq \mathrm{k}+10$ must be true. For the lowest level, $\mathrm{k} 1=\mathrm{k}+10$, where $10 \leq \mathrm{k} 1 \leq 15, \mathrm{k}, \mathrm{k} 1 \in \mathrm{N}^{+}$;

(3) Equation (18-3): $\overline{\mathrm{t}_{0}}=360^{\circ} \rightarrow \mathrm{X}=2025 \cdot 2^{\mathrm{k} 1-\mathrm{k}-14}$. To satisfy $\mathrm{X} \in \mathrm{N}^{+}, \mathrm{k} 1 \geq \mathrm{k}+14$ must be true. For the lowest level, $\mathrm{k} 1=\mathrm{k}+14$, where $\mathrm{k} 1 \geq 16, \mathrm{k}, \mathrm{k} 1 \in \mathrm{N}^{+}$.

The directions of 1 and $\mathrm{r}$ are similar. The corresponding level $\mathrm{k} 2$ for GeoSOT can be calculated by the same method. The results in Table 10 were obtained according to this conclusion.

Table 10. Analysis of the isomorphism between GeoSOT and the World Wind digital Earth grid.

\begin{tabular}{cccccc}
\hline $\mathbf{k}$ & $\mathbf{k} \mathbf{1}$ & $\mathbf{X}$ & $\mathbf{k 2}$ & $\mathbf{Y}$ & $\mathbf{k 0}$ \\
\hline 1 & 7 & 9 & 7 & 9 & 9 \\
2 & 8 & 9 & 8 & 9 & 9 \\
3 & 9 & 9 & 9 & 9 & 9 \\
4 & 14 & 135 & 14 & 135 & 135 \\
5 & 15 & 135 & 15 & 135 & 135 \\
6 & 20 & 2025 & 20 & 2025 & 2025 \\
7 & 21 & 2025 & 21 & 2025 & 2025 \\
8 & 22 & 2025 & 22 & 2025 & 2025 \\
9 & 23 & 2025 & 23 & 2025 & 2025 \\
$\ldots$ & $\ldots$ & $\ldots$ & $\ldots$ & $\ldots$ & $\ldots$ \\
\hline
\end{tabular}

Table 10 shows that different levels of the World Wind digital Earth grid can be obtained by aggregating different GeoSOT levels: Level $7\left(4^{\circ}\right)$, Level $8\left(2^{\circ}\right)$, Level $9\left(1^{\circ}\right)$, Level $14\left(2^{\prime}\right)$, Level $15\left(1^{\prime}\right)$, Level $20\left(2^{\prime \prime}\right)$, Level $21\left(1^{\prime \prime}\right)$, Level $22\left(0.5^{\prime \prime}\right)$, Level 23 and Level 24, etc. Therefore, we conclude that GeoSOT and the World Wind digital Earth grid are isomorphic.

\subsection{Analysis of Weak Isomorphism between Existing Digital Earth Grids and Traditional Map Sheet Grids}

According to the analysis above, GeoSOT is isomorphic to digital Earth grids, and to traditional map sheet grids. To prove the weak isomorphism $(\sim)$ between existing digital Earth grids and traditional topographic map sheet grids, confirmation that existing digital Earth grids traditional map sheet grids is sufficient. 
The example of the World Wind digital Earth grid and the Chinese national topographic map sheet grid with basic scale provides an illustration.

If, in the $\mathrm{t}$ - and $\mathrm{b}$-directions, the $\mathrm{k}^{\text {th }}$ level of the basic scale topographic map sheet grid can be obtained by aggregating the $\mathrm{k} 1^{\text {th }}$ level of the World Wind digital Earth grid, the two grids must satisfy Equation (8). Equation (19) can be obtained from Equations (10) and (14):

$$
\begin{gathered}
\left\{\begin{array}{c}
\frac{\Delta \mathrm{t}_{1}}{2^{\mathrm{k}-1}}=\mathrm{X} \cdot \frac{\overline{\mathrm{t}_{0}}}{10 \cdot 2^{\mathrm{k} 1-1}}, 1 \leq \mathrm{k}<4, \mathrm{k} \in \mathrm{N} \\
\frac{\Delta \mathrm{t}_{1}}{3 \cdot 2^{\mathrm{k}-2}}=\mathrm{X} \cdot \frac{\mathrm{t}_{0}}{10 \cdot 2^{\mathrm{k} 1-1}}, 4 \leq \mathrm{k} \leq 8, \mathrm{k} \in \mathrm{N}
\end{array}\right. \\
\Rightarrow\left\{\begin{array}{c}
\mathrm{X}=10 \cdot 2^{\mathrm{k} 1-\mathrm{k}} \frac{\Delta \mathrm{t}_{1}}{\mathrm{t}_{0}}, 1 \leq \mathrm{k}<4, \mathrm{k} \in \mathrm{N} \\
\mathrm{X}=\frac{10}{3} \cdot 2^{\mathrm{k} 1-\mathrm{k}+1} \frac{\Delta \mathrm{t}_{1}}{\mathrm{t}_{0}}, 4 \leq \mathrm{k} \leq 8, \mathrm{k} \in \mathrm{N}
\end{array}\right.
\end{gathered}
$$

For equation (19-1), $\Delta \mathrm{t}_{1}=6^{\circ}, \overline{\mathrm{t}_{0}}=360^{\circ}$, and $\mathrm{X}=2^{\mathrm{k} 1-\mathrm{k}-1} / 3$; for equation (19-2), we obtain $X=2^{k 1-k} / 9$. Therefore, Equation (19) shows that for any value of $k 1, X \in \mathrm{N}^{+}$cannot be satisfied. Therefore, in the $\mathrm{t}$ - and $\mathrm{b}$-directions, topographic map sheet grids with basic scale cannot be obtained by aggregating the World Wind digital Earth grid. Similarly, in the l- and r-directions, the condition for aggregation cannot be satisfied. Therefore, we conclude that the World Wind digital Earth grid topographic map sheet grids.

Table 11 demonstrates the isomorphism between the GeoSOT grid and topographic map sheet grids, representing the experiment analysis on how the GeoSOT grids aggregate to the topographic map sheets. In particular, the approximation error is the relative error from the ratio of the difference between the region aggregated by digital Earth grids and the topographic map sheet grid to the size of the current digital Earth grid. Seven different topographic map scales are listed in the first column of Table 11, and the map range of each scale is indicated in the second column. The third column represents the selected GeoSOT level for aggregation; the range of the corresponding grids are shown in the fourth column. From the fifth column, we are informed how the selected GeoSOT grids aggregate to the topographic map sheet grids. What is more, the approximation errors are completely $0 \%$, indicating an exact aggregation process from GeoSOT grids to the topographic map sheet grids. The aggregation results for World Wind digital Earth grid is shown in Table 12, demonstrating the weak isomorphism between the World Wind digital Earth grid and topographic map sheet grids. Table 13 shows proof from a similar experiment of weak isomorphism between the Google Earth digital Earth grid and topographic map sheet grids.

Table 11. The experimental analysis of the aggregation from the GeoSOT grid to the topographic map sheets.

\begin{tabular}{cccccc}
\hline Scale & Map Range & $\begin{array}{c}\text { Aggregation of } \\
\mathbf{n}^{\text {th }} \text { Level }\end{array}$ & $\begin{array}{c}\text { The Grid Range of the } \\
\mathbf{n}^{\text {th }} \text { Level for GeoSOT }\end{array}$ & $\begin{array}{c}\text { Aggregation } \\
\text { Number }\end{array}$ & $\begin{array}{c}\text { Approximation } \\
\text { Error }\end{array}$ \\
\hline $1: 1,000,000$ & $6^{\circ} \times 4^{\circ}$ & after $8^{\text {th }}$ Level & $2^{\circ} \times 2^{\circ}$ & $3 \times 2$ & $0 \%$ \\
$1: 500,000$ & $3^{\circ} \times 2^{\circ}$ & after $9^{\text {th }}$ Level & $1^{\circ} \times 1^{\circ}$ & $3 \times 2$ & $0 \%$ \\
$1: 250,000$ & $1^{\circ} 30^{\prime} \times 1^{\circ}$ & after $14^{\text {th }}$ Level & $2^{\prime} \times 2^{\prime}$ & $45 \times 30$ & $0 \%$ \\
$1: 100,000$ & $30^{\prime} \times 20^{\prime}$ & after $14^{\text {th }}$ Level & $2^{\prime} \times 2^{\prime}$ & $15 \times 10$ & $0 \%$ \\
$1: 50,000$ & $15^{\prime} \times 10^{\prime}$ & after $15^{\text {th }}$ Level & $1^{\prime} \times 1^{\prime}$ & $15 \times 10$ & $0 \%$ \\
$1: 25,000$ & $7^{\prime} 30^{\prime \prime} \times 5^{\prime}$ & after 20 $0^{\text {th }}$ Level & $2^{\prime \prime} \times 2^{\prime \prime}$ & $225 \times 150$ & $0 \%$ \\
$1: 10,000$ & $3^{\prime} 45^{\prime \prime} \times 2^{\prime} 30^{\prime \prime}$ & after $21^{\text {th }}$ Level & $1^{\prime \prime} \times 1^{\prime \prime}$ & $225 \times 150$ & $0 \%$ \\
\hline
\end{tabular}


Table 12. The experimental analysis of the aggregation from the World Wind digital Earth grid to the topographic map sheets.

\begin{tabular}{|c|c|c|c|c|c|}
\hline Scale & Map Range & $\begin{array}{l}\text { Aggregation of } \\
\mathbf{n}^{\text {th }} \text { Level }\end{array}$ & $\begin{array}{l}\text { The Grid Range of the } \mathrm{n}^{\text {th }} \text { Level for } \\
\text { World Wind }\end{array}$ & Aggregation Number & Approximation Error \\
\hline $1: 1,000,000$ & $6^{\circ} \times 4^{\circ}$ & 4 & $4^{\circ} 30^{\prime} \times 4^{\circ} 30^{\prime}$ & 2,4 & $68.75 \% \sim 237.5 \%$ \\
\hline $1: 1,000,000$ & $6^{\circ} \times 4^{\circ}$ & 5 & $2^{\circ} 15^{\prime} \times 2^{\circ} 15^{\prime}$ & $6,8,9,12$ & $26.56 \% \sim 153.13 \%$ \\
\hline $1: 1,000,000$ & $6^{\circ} \times 4^{\circ}$ & 6 & $1^{\circ} 7^{\prime} 30^{\prime \prime} \times 1^{\circ} 7^{\prime} 30^{\prime \prime}$ & 24,30 & $26.56 \% \sim 58.20 \%$ \\
\hline $1: 1,000,000$ & $6^{\circ} \times 4^{\circ}$ & 7 & $33^{\prime} 45^{\prime \prime} \times 33^{\prime} 45^{\prime \prime}$ & 88,96 & $16.02 \% \sim 26.56 \%$ \\
\hline $1: 1,000,000$ & $6^{\circ} \times 4^{\circ}$ & 8 & $16^{\prime} 52.5^{\prime \prime} \times 16^{\prime} 52.5^{\prime \prime}$ & 330,352 & $8.76 \% \sim 16.02 \%$ \\
\hline $1: 1,000,000$ & $6^{\circ} \times 4^{\circ}$ & 9 & $8^{\prime} 26.25^{\prime \prime} \times 8^{\prime} 26.25^{\prime \prime}$ & $1247,1276,1290,1320$ & $2.75 \% \sim 8.76 \%$ \\
\hline $1: 500,000$ & $3^{\circ} \times 2^{\circ}$ & 5 & $2^{\circ} 15^{\prime} \times 2^{\circ} 15^{\prime}$ & 2,4 & $68.75 \% \sim 237.5 \%$ \\
\hline $1: 500,000$ & $3^{\circ} \times 2^{\circ}$ & 6 & $1^{\circ} 7^{\prime} 30^{\prime \prime} \times 1^{\circ} 7^{\prime} 30^{\prime \prime}$ & $6,8,9,12$ & $26.56 \% \sim 153.13 \%$ \\
\hline $1: 500,000$ & $3^{\circ} \times 2^{\circ}$ & 7 & $33^{\prime} 45^{\prime \prime} \times 33^{\prime} 45^{\prime \prime}$ & 24,30 & $26.56 \% \sim 58.20 \%$ \\
\hline $1: 500,000$ & $3^{\circ} \times 2^{\circ}$ & 8 & $16^{\prime} 52.5^{\prime \prime} \times 16^{\prime} 52.5^{\prime \prime}$ & 88,96 & $16.02 \% \sim 26.56 \%$ \\
\hline $1: 500,000$ & $3^{\circ} \times 2^{\circ}$ & 9 & $8^{\prime} 26.25^{\prime \prime} \times 8^{\prime} 26.25^{\prime \prime}$ & 330,352 & $8.76 \% \sim 16.02 \%$ \\
\hline $1: 500,000$ & $3^{\circ} \times 2^{\circ}$ & 10 & $4^{\prime} 13.125^{\prime \prime} \times 4^{\prime} 13.125^{\prime \prime}$ & $1247,1276,1290,1320$ & $2.75 \% \sim 8.76 \%$ \\
\hline $1: 250,000$ & $1^{\circ} 30^{\prime} \times 1^{\circ}$ & 6 & $1^{\circ} 7^{\prime} 30^{\prime \prime} \times 1^{\circ} 7^{\prime} 30^{\prime \prime}$ & 2,4 & $68.75 \% \sim 237.5 \%$ \\
\hline $1: 250,000$ & $1^{\circ} 30^{\prime} \times 1^{\circ}$ & 7 & $33^{\prime} 45^{\prime \prime} \times 33^{\prime} 45^{\prime \prime}$ & $6,8,9,12$ & $26.56 \% \sim 153.13 \%$ \\
\hline $1: 250,000$ & $1^{\circ} 30^{\prime} \times 1^{\circ}$ & 8 & $16^{\prime} 52.5^{\prime \prime} \times 16^{\prime} 52.5^{\prime \prime}$ & 24,30 & $26.56 \% \sim 58.20 \%$ \\
\hline $1: 250,000$ & $1^{\circ} 30^{\prime} \times 1^{\circ}$ & 9 & $8^{\prime} 26.25^{\prime \prime} \times 8^{\prime} 26.25^{\prime \prime}$ & 88,96 & $16.02 \% \sim 26.56 \%$ \\
\hline $1: 250,000$ & $1^{\circ} 30^{\prime} \times 1^{\circ}$ & 10 & $4^{\prime} 13.125^{\prime \prime} \times 4^{\prime} 13.125^{\prime \prime}$ & 330,352 & $8.76 \% \sim 16.02 \%$ \\
\hline $1: 250,000$ & $1^{\circ} 30^{\prime} \times 1^{\circ}$ & 11 & $2^{\prime} 6.5625^{\prime \prime} \times 2^{\prime} 6.5625^{\prime \prime}$ & $1247,1276,1290,1320$ & $2.75 \% \sim 8.76 \%$ \\
\hline $1: 100,000$ & $30^{\prime} \times 20^{\prime}$ & 8 & $16^{\prime} 52.5^{\prime \prime} \times 16^{\prime} 52.5^{\prime \prime}$ & $4,6,9$ & $89.84 \% \sim 327.15 \%$ \\
\hline $1: 100,000$ & $30^{\prime} \times 20^{\prime}$ & 9 & $8^{\prime} 26.25^{\prime \prime} \times 8^{\prime} 26.25^{\prime \prime}$ & $12,15,16,20$ & $42.38 \% \sim 137.3 \%$ \\
\hline $1: 100,000$ & $30^{\prime} \times 20^{\prime}$ & 10 & $4^{\prime} 13.125^{\prime \prime} \times 4^{\prime} 13.125^{\prime \prime}$ & 40,48 & $18.65 \% \sim 42.38 \%$ \\
\hline $1: 100,000$ & $30^{\prime} \times 20^{\prime}$ & 11 & $2^{\prime} 6.5625^{\prime \prime} \times 2^{\prime} 6.5625^{\prime \prime}$ & $150,160,165,176$ & $11.24 \% \sim 30.52 \%$ \\
\hline $1: 100,000$ & $30^{\prime} \times 20^{\prime}$ & 12 & $1^{\prime} 3.28125^{\prime \prime} \times 1^{\prime} 3.28125^{\prime \prime}$ & $551,570,580,600$ & $2.15 \% \sim 11.24 \%$ \\
\hline $1: 100,000$ & $30^{\prime} \times 20^{\prime}$ & 13 & $31.640625^{\prime \prime} \times 31.640625^{\prime \prime}$ & $2166,2204,2223,2262$ & $0.39 \% \sim 4.48 \%$ \\
\hline $1: 50,000$ & $15^{\prime} \times 10^{\prime}$ & 9 & $8^{\prime} 26.25^{\prime \prime} \times 8^{\prime} 26.25^{\prime \prime}$ & $4,6,9$ & $89.84 \% \sim 327.15 \%$ \\
\hline $1: 50,000$ & $15^{\prime} \times 10^{\prime}$ & 10 & $4^{\prime} 13.125^{\prime \prime} \times 4^{\prime} 13.125^{\prime \prime}$ & $12,15,16,20$ & $42.38 \% \sim 137.3 \%$ \\
\hline $1: 50,000$ & $15^{\prime} \times 10^{\prime}$ & 11 & $2^{\prime} 6.5625^{\prime \prime} \times 2^{\prime} 6.5625^{\prime \prime}$ & 40,48 & $18.65 \% \sim 42.38 \%$ \\
\hline $1: 50,000$ & $15^{\prime} \times 10^{\prime}$ & 12 & $1^{\prime} 3.28125^{\prime \prime} \times 1^{\prime} 3.28125^{\prime \prime}$ & $150,160,165,176$ & $11.24 \% \sim 30.52 \%$ \\
\hline $1: 50,000$ & $15^{\prime} \times 10^{\prime}$ & 13 & $31.640625^{\prime \prime} \times 31.640625^{\prime \prime}$ & $551,570,580,600$ & $2.15 \% \sim 11.24 \%$ \\
\hline $1: 50,000$ & $15^{\prime} \times 10^{\prime}$ & 14 & $15.8203125^{\prime \prime} \times 15.8203125^{\prime \prime}$ & $2166,2204,2223,2262$ & $0.39 \% \sim 4.48 \%$ \\
\hline $1: 25,000$ & $7^{\prime} 30^{\prime \prime} \times 5^{\prime}$ & 10 & $4^{\prime} 13.125^{\prime \prime} \times 4^{\prime} 13.125^{\prime \prime}$ & $4,6,9$ & $89.84 \% \sim 327.15 \%$ \\
\hline $1: 25,000$ & $7^{\prime} 30^{\prime \prime} \times 5^{\prime}$ & 11 & $2^{\prime} 6.5625^{\prime \prime} \times 2^{\prime} 6.5625^{\prime \prime}$ & $12,15,16,20$ & $42.38 \% \sim 137.3 \%$ \\
\hline $1: 25,000$ & $7^{\prime} 30^{\prime \prime} \times 5^{\prime}$ & 12 & $1^{\prime} 3.28125^{\prime \prime} \times 1^{\prime} 3.28125^{\prime \prime}$ & 40,48 & $18.65 \% \sim 42.38 \%$ \\
\hline $1: 25,000$ & $7^{\prime} 30^{\prime \prime} \times 5^{\prime}$ & 13 & $31.640625^{\prime \prime} \times 31.640625^{\prime \prime}$ & $150,160,165,176$ & $11.24 \% \sim 30.52 \%$ \\
\hline $1: 25,000$ & $7^{\prime} 30^{\prime \prime} \times 5^{\prime}$ & 14 & $15.8203125^{\prime \prime} \times 15.8203125^{\prime \prime}$ & $551,570,580,600$ & $2.15 \% \sim 11.24 \%$ \\
\hline $1: 25,000$ & $7^{\prime} 30^{\prime \prime} \times 5^{\prime}$ & 15 & $7.91015625^{\prime \prime} \times 7.91015625^{\prime \prime}$ & $2166,2204,2223,2262$ & $0.39 \% \sim 4.48 \%$ \\
\hline $1: 10,000$ & $3^{\prime} 45^{\prime \prime} \times 2^{\prime} 30^{\prime \prime}$ & 11 & $2^{\prime} 6.5625^{\prime \prime} \times 2^{\prime} 6.5625^{\prime \prime}$ & $4,6,9$ & $89.84 \% \sim 327.15 \%$ \\
\hline $1: 10,000$ & $3^{\prime} 45^{\prime \prime} \times 2^{\prime} 30^{\prime \prime}$ & 12 & $1^{\prime} 3.28125^{\prime \prime} \times 1^{\prime} 3.28125^{\prime \prime}$ & $12,15,16,20$ & $42.38 \% \sim 137.3 \%$ \\
\hline $1: 10,000$ & $3^{\prime} 45^{\prime \prime} \times 2^{\prime} 30^{\prime \prime}$ & 13 & $31.640625^{\prime \prime} \times 31.640625^{\prime \prime}$ & 40,48 & $18.65 \% \sim 42.38 \%$ \\
\hline $1: 10,000$ & $3^{\prime} 45^{\prime \prime} \times 2^{\prime} 30^{\prime \prime}$ & 14 & $15.8203125^{\prime \prime} \times 15.8203125^{\prime \prime}$ & $150,160,165,176$ & $11.24 \% \sim 30.52 \%$ \\
\hline $1: 10,000$ & $3^{\prime} 45^{\prime \prime} \times 2^{\prime} 30^{\prime \prime}$ & 15 & $7.91015625^{\prime \prime} \times 7.91015625^{\prime \prime}$ & $551,570,580,600$ & $2.15 \% \sim 11.24 \%$ \\
\hline $1: 10,000$ & $3^{\prime} 45^{\prime \prime} \times 2^{\prime} 30^{\prime \prime}$ & 16 & $3.955078125^{\prime \prime} \times 3.955078125^{\prime \prime}$ & $2166,2204,2223,2262$ & $0.39 \% \sim 4.48 \%$ \\
\hline
\end{tabular}


Table 13. The experimental analysis of the aggregation from the Google Earth digital Earth grid to the topographic map sheets.

\begin{tabular}{|c|c|c|c|c|c|}
\hline Scale & Map Range & $\begin{array}{l}\text { Aggregation of } \\
\mathrm{n}^{\text {th }} \text { Level }\end{array}$ & $\begin{array}{l}\text { The Grid Range of the } n^{\text {th }} \text { Level } \\
\text { for Google Earth }\end{array}$ & Aggregation Number & Approximation Erro \\
\hline $1: 1,000,000$ & $6^{\circ} \times 4^{\circ}$ & 6 & $5^{\circ} 37^{\prime} 30^{\prime \prime} \times 2^{\circ} 48^{\prime} 45^{\prime \prime}$ & 4,6 & $163.67 \% \sim 295.51 \%$ \\
\hline $1: 1,000,000$ & $6^{\circ} \times 4^{\circ}$ & 7 & $2^{\circ} 48^{\prime} 45^{\prime \prime} \times 1^{\circ} 24^{\prime} 22.5^{\prime \prime}$ & $9,12,16$ & $48.32 \% \sim 163.67 \%$ \\
\hline $1: 1,000,000$ & $6^{\circ} \times 4^{\circ}$ & 8 & $1^{\circ} 24^{\prime} 22.5^{\prime \prime} \times 42^{\prime} 11.25^{\prime \prime}$ & $30,35,36,42$ & $23.60 \% \sim 73.03 \%$ \\
\hline $1: 1,000,000$ & $6^{\circ} \times 4^{\circ}$ & 9 & $42^{\prime} 11.25^{\prime \prime} \times 21^{\prime} 5.625^{\prime \prime}$ & $108,117,120,130$ & $11.24 \% \sim 33.90 \%$ \\
\hline $1: 1,000,000$ & $6^{\circ} \times 4^{\circ}$ & 10 & $21^{\prime} 5.625^{\prime \prime} \times 10^{\prime} 32.8125^{\prime \prime}$ & 414,432 & $6.60 \% \sim 11.24 \%$ \\
\hline $1: 1,000,000$ & $6^{\circ} \times 4^{\circ}$ & 11 & $10^{\prime} 32.8125^{\prime \prime} \times 5^{\prime} 16.40625^{\prime \prime}$ & $1610,1645,1656,1692$ & $3.64 \% \sim 8.92 \%$ \\
\hline $1: 500,000$ & $3^{\circ} \times 2^{\circ}$ & 7 & $2^{\circ} 48^{\prime} 45^{\prime \prime} \times 1^{\circ} 24^{\prime} 22.5^{\prime \prime}$ & 4,6 & $163.67 \% \sim 295.51 \%$ \\
\hline $1: 500,000$ & $3^{\circ} \times 2^{\circ}$ & 8 & $1^{\circ} 24^{\prime} 22.5^{\prime \prime} \times 42^{\prime} 11.25^{\prime \prime}$ & $9,12,16$ & $48.32 \% \sim 163.67 \%$ \\
\hline $1: 500,000$ & $3^{\circ} \times 2^{\circ}$ & 9 & $42^{\prime} 11.25^{\prime \prime} \times 21^{\prime} 5.625^{\prime \prime}$ & $30,35,36,42$ & $23.60 \% \sim 73.03 \%$ \\
\hline $1: 500,000$ & $3^{\circ} \times 2^{\circ}$ & 10 & $21^{\prime} 5.625^{\prime \prime} \times 10^{\prime} 32.8125^{\prime \prime}$ & $108,117,120,130$ & $11.24 \% \sim 33.90 \%$ \\
\hline $1: 500,000$ & $3^{\circ} \times 2^{\circ}$ & 11 & $10^{\prime} 32.8125^{\prime \prime} \times 5^{\prime} 16.40625^{\prime \prime}$ & 414,432 & $6.60 \% \sim 11.24 \%$ \\
\hline $1: 500,000$ & $3^{\circ} \times 2^{\circ}$ & 12 & $5^{\prime} 16.40625^{\prime \prime} \times 2^{\prime} 38.203125^{\prime \prime}$ & $1610,1645,1656,1692$ & $3.64 \% \sim 8.92 \%$ \\
\hline $1: 250,000$ & $1^{\circ} 30^{\prime} \times 1^{\circ}$ & 8 & $1^{\circ} 24^{\prime} 22.5^{\prime \prime} \times 42^{\prime} 11.25^{\prime \prime}$ & 4,6 & $163.67 \% \sim 295.51 \%$ \\
\hline $1: 250,000$ & $1^{\circ} 30^{\prime} \times 1^{\circ}$ & 9 & $42^{\prime} 11.25^{\prime \prime} \times 21^{\prime} 5.625^{\prime \prime}$ & $9,12,16$ & $48.32 \% \sim 163.67 \%$ \\
\hline $1: 250,000$ & $1^{\circ} 30^{\prime} \times 1^{\circ}$ & 10 & $21^{\prime} 5.625^{\prime \prime} \times 10^{\prime} 32.8125^{\prime \prime}$ & $30,35,36,42$ & $23.60 \% \sim 73.03 \%$ \\
\hline $1: 250,000$ & $1^{\circ} 30^{\prime} \times 1^{\circ}$ & 11 & $10^{\prime} 32.8125^{\prime \prime} \times 5^{\prime} 16.40625^{\prime \prime}$ & $108,117,120,130$ & $11.24 \% \sim 33.90 \%$ \\
\hline $1: 250,000$ & $1^{\circ} 30^{\prime} \times 1^{\circ}$ & 12 & $5^{\prime} 16.40625^{\prime \prime} \times 2^{\prime} 38.203125^{\prime \prime}$ & 414,432 & $6.60 \% \sim 11.24 \%$ \\
\hline $1: 250,000$ & $1^{\circ} 30^{\prime} \times 1^{\circ}$ & 13 & $2^{\prime} 38.203125^{\prime \prime} \times 1^{\prime} 19.1015625^{\prime \prime}$ & $1610,1645,1656,1692$ & $3.64 \% \sim 8.92 \%$ \\
\hline $1: 100,000$ & $30^{\prime} \times 20^{\prime}$ & 10 & $21^{\prime} 5.625^{\prime \prime} \times 10^{\prime} 32.8125^{\prime \prime}$ & $4,6,9$ & $48.32 \% \sim 233.71 \%$ \\
\hline $1: 100,000$ & $30^{\prime} \times 20^{\prime}$ & 11 & $10^{\prime} 32.8125^{\prime \prime} \times 5^{\prime} 16.40625^{\prime \prime}$ & $12,15,16,20$ & $11.24 \% \sim 85.39 \%$ \\
\hline $1: 100,000$ & $30^{\prime} \times 20^{\prime}$ & 12 & $5^{\prime} 16.40625^{\prime \prime} \times 2^{\prime} 38.203125^{\prime \prime}$ & $48,54,56,63$ & $11.24 \% \sim 46 \%$ \\
\hline $1: 100,000$ & $30^{\prime} \times 20^{\prime}$ & 13 & $2^{\prime} 38.203125^{\prime \prime} \times 1^{\prime} 19.1015625^{\prime \prime}$ & $192,204,208,221$ & $11.24 \% \sim 28.04 \%$ \\
\hline $1: 100,000$ & $30^{\prime} \times 20^{\prime}$ & 14 & $1^{\prime} 19.1015625^{\prime \prime} \times 39.55078125^{\prime \prime}$ & $713,736,744,768$ & $3.27 \% \sim 11.24 \%$ \\
\hline $1: 100,000$ & $30^{\prime} \times 20^{\prime}$ & 15 & $39.55078125^{\prime \prime} \times 19.775390625^{\prime \prime}$ & $2806,2852,2867,2914$ & $1.6 \% \sim 5.52 \%$ \\
\hline $1: 50,000$ & $15^{\prime} \times 10^{\prime}$ & 11 & $10^{\prime} 32.8125^{\prime \prime} \times 5^{\prime} 16.40625^{\prime \prime}$ & $4,6,9$ & $48.32 \% \sim 233.71 \%$ \\
\hline $1: 50,000$ & $15^{\prime} \times 10^{\prime}$ & 12 & $5^{\prime} 16.40625^{\prime \prime} \times 2^{\prime} 38.203125^{\prime \prime}$ & $12,15,16,20$ & $11.24 \% \sim 85.39 \%$ \\
\hline $1: 50,000$ & $15^{\prime} \times 10^{\prime}$ & 13 & $2^{\prime} 38.203125^{\prime \prime} \times 1^{\prime} 19.1015625^{\prime \prime}$ & $48,54,56,63$ & $11.24 \% \sim 46 \%$ \\
\hline $1: 50,000$ & $15^{\prime} \times 10^{\prime}$ & 14 & $1^{\prime} 19.1015625^{\prime \prime} \times 39.55078125^{\prime \prime}$ & $192,204,208,221$ & $11.24 \% \sim 28.04 \%$ \\
\hline $1: 50,000$ & $15^{\prime} \times 10^{\prime}$ & 15 & $39.55078125^{\prime \prime} \times 19.775390625^{\prime \prime}$ & $713,736,744,768$ & $3.27 \% \sim 11.24 \%$ \\
\hline $1: 50,000$ & $15^{\prime} \times 10^{\prime}$ & 16 & $19.775390625^{\prime \prime} \times 9.8876953125^{\prime \prime}$ & $2806,2852,2867,2914$ & $1.6 \% \sim 5.52 \%$ \\
\hline $1: 25,000$ & $7^{\prime} 30^{\prime \prime} \times 5^{\prime}$ & 12 & $5^{\prime} 16.40625^{\prime \prime} \times 2^{\prime} 38.203125^{\prime \prime}$ & $4,6,9$ & $48.32 \% \sim 233.71 \%$ \\
\hline $1: 25,000$ & $7^{\prime} 30^{\prime \prime} \times 5^{\prime}$ & 13 & $2^{\prime} 38.203125^{\prime \prime} \times 1^{\prime} 19.1015625^{\prime \prime}$ & $12,15,16,20$ & $11.24 \% \sim 85.39 \%$ \\
\hline $1: 25,000$ & $7^{\prime} 30^{\prime \prime} \times 5^{\prime}$ & 14 & $1^{\prime} 19.1015625^{\prime \prime} \times 39.55078125^{\prime \prime}$ & $48,54,56,63$ & $11.24 \% \sim 46 \%$ \\
\hline $1: 25,000$ & $7^{\prime} 30^{\prime \prime} \times 5^{\prime}$ & 15 & $39.55078125^{\prime \prime} \times 19.775390625^{\prime \prime}$ & $192,204,208,221$ & $11.24 \% \sim 28.04 \%$ \\
\hline $1: 25,000$ & $7^{\prime} 30^{\prime \prime} \times 5^{\prime}$ & 16 & $19.775390625^{\prime \prime} \times 9.8876953125^{\prime \prime}$ & $713,736,744,768$ & $3.27 \% \sim 11.24 \%$ \\
\hline $1: 25,000$ & $7^{\prime} 30^{\prime \prime} \times 5^{\prime}$ & 17 & $9.8876953125^{\prime \prime} \times 4.94384765625^{\prime \prime}$ & $2806,2852,2867,2914$ & $1.6 \% \sim 5.52 \%$ \\
\hline $1: 10,000$ & $3^{\prime} 45^{\prime \prime} \times 2^{\prime} 30^{\prime \prime}$ & 13 & $2^{\prime} 38.203125^{\prime \prime} \times 1^{\prime} 19.1015625^{\prime \prime}$ & $4,6,9$ & $48.32 \% \sim 233.71 \%$ \\
\hline $1: 10,000$ & $3^{\prime} 45^{\prime \prime} \times 2^{\prime} 30^{\prime \prime}$ & 14 & $1^{\prime} 19.1015625^{\prime \prime} \times 39.55078125^{\prime \prime}$ & $12,15,16,20$ & $11.24 \% \sim 85.39 \%$ \\
\hline $1: 10,000$ & $3^{\prime} 45^{\prime \prime} \times 2^{\prime} 30^{\prime \prime}$ & 15 & $39.55078125^{\prime \prime} \times 19.775390625^{\prime \prime}$ & $48,54,56,63$ & $11.24 \% \sim 46 \%$ \\
\hline $1: 10,000$ & $3^{\prime} 45^{\prime \prime} \times 2^{\prime} 30^{\prime \prime}$ & 16 & $19.775390625^{\prime \prime} \times 9.8876953125^{\prime \prime}$ & $192,204,208,221$ & $11.24 \% \sim 28.04 \%$ \\
\hline $1: 10,000$ & $3^{\prime} 45^{\prime \prime} \times 2^{\prime} 30^{\prime \prime}$ & 17 & $9.8876953125^{\prime \prime} \times 4.94384765625^{\prime \prime}$ & $713,736,744,768$ & $3.27 \% \sim 11.24 \%$ \\
\hline $1: 10,000$ & $3^{\prime} 45^{\prime \prime} \times 2^{\prime} 30^{\prime \prime}$ & 18 & $4.94384765625 " \times 2.471923828125 "$ & $2806,2852,2867,2914$ & $1.6 \% \sim 5.52 \%$ \\
\hline
\end{tabular}


Figure 6 shows the error approximation changes for the normal map sheet grids aggregated from the World Wind digital Earth grid, the Google Earth digital Earth grid, and GeoSOT, with the example of 1:1,000,000 map sheet areas. This confirms that World Wind digital Earth grid topographic map sheet grids, Google Earth digital Earth grid topographic map sheet grids, and GeoSOT $\simeq$ topographic map sheet grids. Similar analyses are also applicable to world map, OSG, Skyline, and other digital Earth grids.

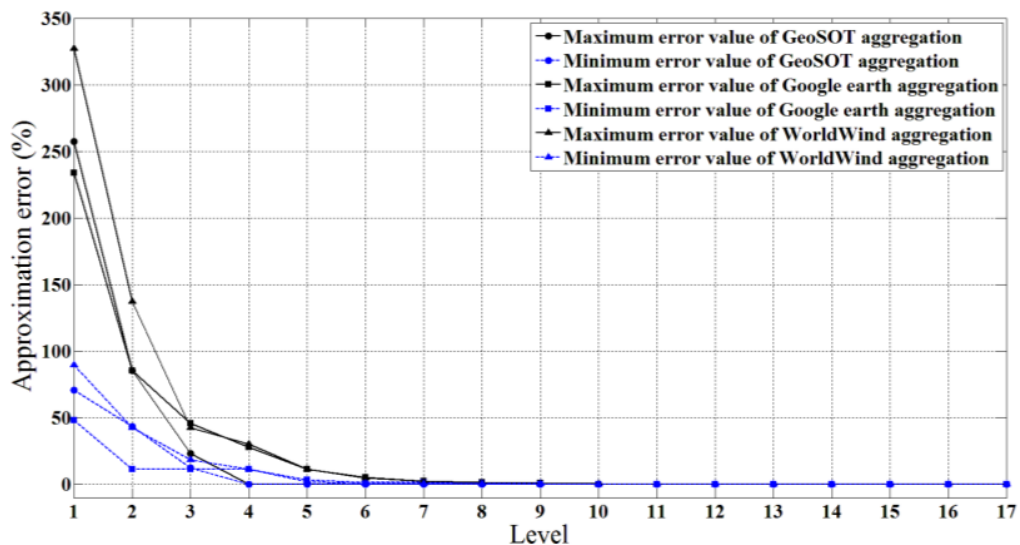

(a)

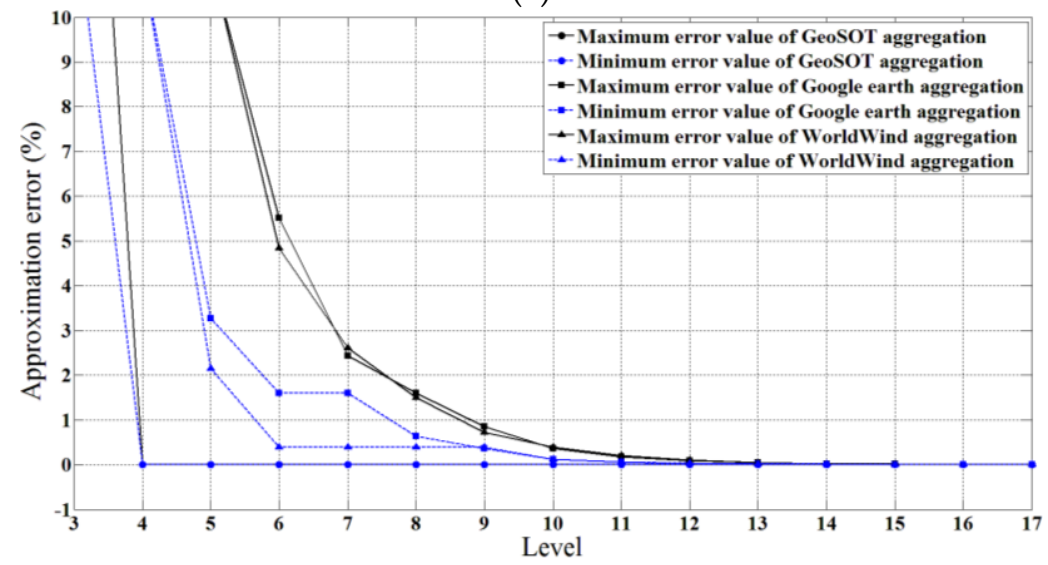

(b)

Figure 6. The trend of error approximation when the GeoSOT grid, World Wind digital Earth grid and the Google Earth digital Earth grid are aggregated to the topographic map sheets (with 1:1,000,000 scales as examples). (a) Full curve figure; (b) local curve figure.

\section{Conclusions and Future Work}

The GeoSOT grid designed in this study is a latitude and longitude subdivision grid that divides with $2^{\mathrm{n}}$ equal-length latitude and longitudes, and forms integer hierarchical grids at degree, minute, and second levels. GeoSOT, on the one hand, is hierarchical like the multi-dimensional quadtree digital Earth grid and, on the other hand, is more consistent with typical mapping, meteorology, oceanography, national geographic and 3D digital Earth grids. The grid can accurately express integer spatial regions at the degree, minute, and second level when there is no input error, which cannot be accomplished by existing grids.

As the demand for cross-industry applications in spatial data grows, the consistency of GeoSOT will be beneficial for the exchange and sharing of different types of spatial data. It could potentially become the reference grid for cross-industry spatial information foundational infrastructure and realize integrated organization and management of different bodies of spatial information from multiple sources. 
GeoSOT allows different bodies of spatial information from multiple sources to use the same set of grid codes, thereby achieving coding uniformity. Through the use of similar encoding in navigation services and network addresses, GeoSOT can provide technical support for rapid sharing, efficient query retrieval, and other operational services for the four national spatial information systems: the remotely sensing and Earth observing system, the geographic information system, the navigation and positioning system, and the computer network system.

Acknowledgments: Portions of this research were supported by the National Basic Research Program of China (973 Program) under cooperative agreement 61399 and by the National Natural Science Foundation of China under cooperative agreement 41671409 and 41201392.

Author Contributions: The first author Chengqi Cheng conceived the study and developed the technical flow of the method; the correspondence author Xiaochong Tong helped optimize the program and wrote the program; the third Bo Chen and fourth authors Weixin Zhai revised the paper.

Conflicts of Interest: The authors declare no conflict of interest.

\section{References}

1. Zhou, C.; Yang, O.U.; Ting, M.A. Progresses of Geographical grid systems researches. Prog. Geogr. 2009, 28, 657-662.

2. Cheng, C. The global subdivision grid based on extended mapping division and its address coding. Acta Geod. Cartogr. Sin. 2010, 39, 295-302.

3. Du, Y. Study the Key Technologies of Global Multi-Resolution Virtual Terrain; Zhengzhou Institute of Surveying \& Mapping: Zhengzhou, China, 2005.

4. Geng, X.H.; Cheng, C.Q.; Song, S.H.; Li, D.P. Global subdivision systems based on map kilo-grids. Geogr. Geo-Inf. Sci. 2010, 26, 15-18.

5. Li, L.; Zhu, X.; Cao, W. Geographic Grid; GB/T 12409-2009; Standards Press of China: Beijing, China, 2009.

6. Goodchild, M.F. Discrete Global Grids for Digital Earth. Available online: http://www.ncgia.ucsb.edu/ globalgrids/papers/goodchild.pdf (accessed on 13 June 2010).

7. Sahr, K. Icosahedral Modified Generalized Balanced Ternary and Aperture 3 Hexagon Tree. U.S. Patent $\# 07,876,967,25$ January 2011.

8. Tong, X.; Ben, J.; Wang, Y.; Zhang, Y. Efficient encoding and spatial operation scheme for aperture 4 hexagonal discrete global grid system. Int. J. Geogr. Inf. Sci. 2013, 27, 898-921. [CrossRef]

9. Mahdavi-Amiri, A.; Samavati, F.; Peterson, P. Categorization and conversions for indexing methods of discrete global grid systems. ISPRS Int. J. Geo-Inf. 2015, 4, 320-336. [CrossRef]

10. Lukatela, H.; Lukatela, H. Hipparchus geopositioning model: An overview. In Proceedings of the Eighth International Symposium on Computer-Assisted Cartography, Baltimore, MD, USA, 29 March-3 April 1987.

11. Mahdavi-Amiri, A.; Harrison, E.; Samavati, F. Hexagonal connectivity maps for digital earth. Int. J. Digit. Earth 2014, 8, 1-20. [CrossRef]

12. Sahr, K. Location coding on icosahedral aperture 3 hexagon discrete global grids. Comput. Environ. Urban Syst. 2008, 32, 174-187. [CrossRef]

13. Dutton, G.H. A Hierarchical Coordinate System for Geoprocessing and Cartography; Springer: Berlin, Germany, 1999.

14. Mahdavi-Amiri, A.; Harrison, E.; Samavati, F. Hierarchical grid conversion. Comput. Aided Des. 2016, 79, 12-26. [CrossRef]

15. National Aeronautics and Space Administration (NASA). World Wind. Available online: http://worldwind. arc.nasa.gov (accessed on 18 July 2011).

16. Koller, D.; Lindstrom, P.; Ribarsky, W.; Hodges, L.F.; Faust, N.; Turner, G. Virtual GIS: A real-time 3D geographic information system. In Proceedings of the IEEE Conference on Visualization, Atlanta, GA, USA, 29 October-3 November 2011.

17. Falby, J.S.; Zyda, M.J.; Pratt, D.R.; Mackey, R.L. NPSNET: Hierarchical data structures for real-time three-dimensional visual simulation. Comput. Graph. 2010, 17, 65-69. [CrossRef]

18. Mahdavi-Amiri, A.; Alderson, T.; Samavati, F. A survey of digital earth. Comput. Graph. 2015, 53, 95-117. [CrossRef]

19. Reddy, M.; Eriksen, M.; Leclerc, Y.; Brecht, J.; Colleen, D.; Reddy, M. SRI's Digital Earth Project; Technical Note 560; SRI International: Menlo Park, CA, USA, 2002. 
20. Ottoson, P.; Hauska, H. Ellipsoidal quadtrees for indexing of global geographical data. Int. J. Geogr. Inf. Sci. 2002, 16, 213-226. [CrossRef]

21. Gong, J. Advances in Data Processing and Analysis of Earth Observation; Wuhan University Press: Wuhan, China, 2007.

22. Federation of American Scientists (FAS). Digital Terrain Elevation Data. Available online: http://fas.org/ $\mathrm{irp} /$ program/core/dted.htm (accessed on 24 January 2008).

23. Bjørke, J.T.; Grytten, J.K.; Hager, M.; Nilsen, S. A global grid model based on "constant area" quadrilaterals. In Proceedings of the Scangis'2003-The Scandinavian Research Conference on Geographical Information Science, Espoo, Finland, 4-6 June 2003.

24. Purse, M.; Oliver, S.; Lewis, A.; Minchin, S.; Wyborn, L.; Gibb, R.; Fraser, A.; Evans, B. Specification of a global nested grid system for use by Australia and New Zealand. In Proceedings of the 7th eResearch Australasia Conference, Brisbane, Australia, 20-25 October 2013.

25. Mahdavi-Amiri, A.; Bhojani, F.; Samavati, F. One-to-two digital earth. Adv. Vis. Comput. 2013, 8034, 681-692.

26. Gorski, K.M.; Hivon, E.; Banday, A.J.; Wandelt, B.D.; Hansen, F.K.; Reinecke, M.; Bartelman, M. HEALPix-A framework for high resolution discretization, and fast analysis of data distributed on the sphere. Astrophys. J. 2005, 622, 759-771. [CrossRef]

27. Zhou, M.; Chen, J.; Gong, J. A pole-oriented discrete global grid system: Quaternary quadrangle mesh. Comput. Geosci. 2013, 61, 133-143. [CrossRef]

28. International Satellite Cloud Climatology Project (ISCCP). ISCCP Map Grid Information. Available online: http:/ / isccp.giss.nasa.gov/docs/mapgridinfo.html (accessed on 23 July 2014).

29. Network Control Language (NCL). POP Grid. Available online: http:/ / www.ncl.ucar.edu/Applications / popgrid.shtml (accessed on 18 March 2015).

30. Network Control Language (NCL). ORCA Grid. Available online: http://www.ncl.ucar.edu/Applications / orca.shtml (accessed on 18 March 2015).

31. United States National Guard (USNG). U.S. National Grid Information Center. Available online: http: / /www.usngcenter.org (accessed on 3 September 2016).

32. The Department of the Army (DA). Map Reading and Land Navigation: FM 3-25.26. Available online: https: //www.amazon.com/Map-Reading-Land-Navigation-3-25-26/dp/1460970837 (accessed on 6 September 2016).

33. National Graphical Association (NGA). GARS. Available online: http://earth-info.nga.mil/GandG/ coordsys/grids/gars.html (accessed on 15 September 2014).

34. Lu, N. Research on Navigation Grid Code; Peking University: Beijing, China, 2013.

35. Lu, Y.; Liu, X.; Guo, Y. Subdivision and Numbering for the National Primary Scale Topographic Maps; GB/T 13989-2012; Standards Press of China: Beijing, China, 2012.

(C) 2016 by the authors; licensee MDPI, Basel, Switzerland. This article is an open access article distributed under the terms and conditions of the Creative Commons Attribution (CC-BY) license (http://creativecommons.org/licenses/by/4.0/). 